\title{
Diversification of 4'-Methylated Nucleosides by Nucleoside Phosphorylases
}

\section{Supporting Information}

Felix Kaspar, ${ }^{\text {a,b* }}$ Margarita Seeger, ${ }^{c}$ Sarah Westarp, ${ }^{\mathrm{a}, \mathrm{b}}$ Christoph Köllmann, ${ }^{d}$ Anna P. Lehmann, ${ }^{d}$ Patrick Pausch, ${ }^{\text {e, }}$ Sebastian Kemper, ${ }^{\mathrm{f}}$ Peter Neubauer, ${ }^{\text {a }}$ Gert Bange, ${ }^{\mathrm{e}}$ Anett Schallmey, ${ }^{\mathrm{c}}$ Daniel B. Werz, ${ }^{\mathrm{d}}$ Anke Kurreck ${ }^{a, b}$

${ }^{a}$ Chair of Bioprocess Engineering, Technische Universität Berlin, Ackerstraße 76, 13355 Berlin, Germany

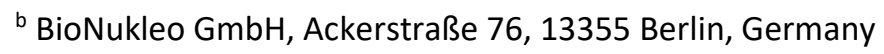

c Technische Universität Braunschweig, Institute for Biochemistry, Biotechnology and Bioinformatics, Spielmannstraße 7, 38106, Braunschweig, Germany

d Technische Universität Braunschweig, Institute of Organic Chemistry, Hagenring 30, 38106, Braunschweig, Germany

e Center for Synthetic Microbiology (SYNMIKRO) \& Department of Chemistry, Philipps-University Marburg Hans-Meerwein-Strasse 6, C07, 35043 Marburg, Germany

f Institute for Chemistry, Technische Universität Berlin, Straße des 17. Juni 135, 10623 Berlin, Germany

\# Present address: Innovative Genomics Institute, University of California, Berkeley, 2151 Berkeley Way, Berkeley, CA 94720, USA

*felix.kaspar@web.de 


\section{Table of Contents}

Author contributions 3

Data availability 3

General remarks 3

Enzymes 5

$\begin{array}{lc}\text { Experimental details and supplementary items } & 6\end{array}$

$\begin{array}{ll}\text { Cloning, expression and purification } & 6\end{array}$

$\begin{array}{ll}\text { Phosphorolysis reactions and reaction monitoring by UV spectroscopy } & 6\end{array}$

$\begin{array}{ll}\text { Enzyme screening } & 7\end{array}$

NMR analysis of 3

$\begin{array}{lr}\text { Kinetic experiments with TtPyNP } & 10\end{array}$

Thermodynamic control of phosphorolysis of 1a 11

$\begin{array}{ll}\text { Transglycosylations } & 14\end{array}$

$\begin{array}{ll}\text { Stability analysis of } 3 & 21\end{array}$

Synthesis of 1e 24

Docking of nucleoside substrates $\quad 25$

Crystallographic methods $\quad 26$

NMR spectra $\quad 30$

Supplementary references $\quad 34$ 
Author contributions (with definitions as recommended by Brand et al. ${ }^{[1]}$ )

Conceptualization, F.K.; Data curation, F.K., P.P.; Formal analysis, F.K., R.S., S.W., P.P. and S.K.; Funding acquisition, P.N., G.B., D.B.W., A.S. and A.K.; Investigation, F.K., R.S., S.W., C.K., A.P.L., P.P. and S.K.; Methodology, F.K., R.S., S.W. and S.K.; Project administration, F.K.; Resources, P.N., G.B., D.B.W., A.S. and A.K.; Software, - ; Supervision, F.K.; Validation, - ; Visualization, F.K. and P.P.; Writing-original draft, F.K.; Writing-review \& editing, all authors.

\section{Data availability}

All data depicted visually in the items in the main text (Figures 1-3) as well as in the Supplementary Information (Figures S1-S16, see below) are available as tabulated data from the text below and from the externally hosted Supplementary Information at zenodo.org. ${ }^{[2]}$ The data and model of GtPyNP with bound uridine were deposited to the Protein Data Bank (PDB) under accession code 7m7k.

\section{General remarks}

All chemicals used in this study were of analytical grade or higher and purchased from Sigma Aldrich (Steinheim, Germany), Carbosynth (Berkshire, UK), Carl Roth (Karlsruhe, Germany), TCI Deutschland (Eschborn, Germany) or VWR (Darmstadt, Germany) and used without prior purification. 4'Methyluridine (1a) was synthesized as described recently. ${ }^{[3]}$ Water deionized to $18.2 \mathrm{M} \Omega \cdot \mathrm{cm}$ with a Werner water purification system was used for the preparation of all enzymatic reactions as well as purification and storage buffers. For the preparation of $\mathrm{NaOH}$ solutions for quenching, deionized water was used. Analytical HPLC analyses were carried out with an Agilent 1200 series system equipped with an Agilent DAD detector and a Phenomenex (Aschaffenburg, Germany) reversed phase Kinetex EVO C18 column $(250 \times 4.6 \mathrm{~mm})$. Elution was performed at a flow rate of $1 \mathrm{~mL} \mathrm{~min}^{-1}$ by running $3 \% \mathrm{MeCN}$ in $20 \mathrm{mM}$ ammonium acetate buffer for $5 \mathrm{~min}$, followed by a linear gradient to $40 \% \mathrm{MeCN}$ in $20 \mathrm{mM}$ ammonium acetate buffer over $20 \mathrm{~min}$. Eluting compounds were detected at $260 \mathrm{~nm}$. Preparative HPLC was carried out using a Knauer HPLC system equipped with a Smartline Detector 2600 and two AZURA P $2.1 \mathrm{~L}$ pumps, equipped with $11 \mathrm{~mL}$ ss pump heads. A flow rate of $21.24 \mathrm{~mL} \mathrm{~min}^{-1}$ and a Kinetex ${ }^{\otimes} 5 \mu \mathrm{m}$ EVO C18 $250 \times 21.2 \mathrm{~mm}$ RP column were used with deionized water and chromatography-grade MeCN as eluents. Nuclear magnetic resonance (NMR) spectra were recorded on a Bruker AVIII 500 or AVIII 700 with the deuterated solvent acting as an internal deuterium lock. ${ }^{1} \mathrm{H}$ and ${ }^{13} \mathrm{C}$ NMR spectra are referenced to sodium trimethylsilylpropansulfonate (DSS) as internal standard. The chemical shift of DSS was set to $0 \mathrm{ppm} .{ }^{[4]}{ }^{31} \mathrm{P}$ NMR spectra were calibrated according to the IUPAC recommendation, using a unified chemical shift scale based on the proton resonance of tetramethylsilane as the primary reference ${ }^{[4]}$ Data are reported as follows: chemical shift, multiplicity $(s=$ singlet, $d=$ doublet, $t=$ triplet, $q=$ quartet, $m=$ multiplet), coupling constant(s) $(\mathrm{Hz})$, and integration. High resolution mass 
spectrometry (HRMS) data were collected by MS service of the Technische University Berlin by LC-MS analysis of samples. To this end, chromatography was performed on a Grom-Sil-120-ODS-4-HE (Grace) column (length $50 \mathrm{~mm}$, ID $2 \mathrm{~mm}, 3 \mu \mathrm{m}$ ) running a linear gradient of $20 \% \mathrm{MeCN}(+0.1 \%$ formic acid) in $\mathrm{H}_{2} \mathrm{O}$ (+ $0.1 \%$ formic acid) over $10 \mathrm{~min}$ at a flow rate of $0.3 \mathrm{~mL} \mathrm{~min}^{-1}$, followed by a column wash with $100 \%$ MeCN (+ 0.1\% formic acid), and HRMS data was collected on a Thermo Fisher Scientific LTQ Orbitrap XL with electrospray ionization. Data handling and routine calculations were carried out in Excel or LibreOffice, NMR data analysis in MestreNova, MS data analysis in Proteowizard and openchrom, fitting and data plotting in OriginLab, metadata writing for spectral unmixing in LibreOffice, spectral unmixing with data_toolbox, ${ }^{[5,6]}$ modelling and docking in YASARA and protein viewing in ChimeraX. ${ }^{[7]}$ Crystallographic software is described below. 


\section{Enzymes}

Thermus thermophilus pyrimidine nucleoside phosphorylase (TtPyNP)

Uniprot ID Q5SHF9_THET8.

Geobacillus thermoglucosidasius pyrimidine nucleoside phosphorylase (GtPyNP)

Uniprot ID A0A369WPE5_PARTM.

Geobacillus thermoglucosidasius purine nucleoside phosphorylase (GtPNP)

Uniprot ID A0A178U1V7_PARTM.

Escherichia coli thymidine phosphorylase (ECTP)

Uniprot ID TYPH_ECODH

TtPyNP-S83T was ordered as a synthetic gene from GeneArt (Invitrogen).

MNPVAFIREKREGKKHRREDLEAFLLGYLRDEVPDYQVSAWLMAAFLRGLDPEETLWLTETMARSGKVLDLSGLPH

PVDKHSTGGVGDKVSLVVGPILAASGCTFAKMSGRGLAHTGGTIDKLESVPGWRGEMTEAEFLERARRVGLVIAA

QSPDLAPLDGKLYALRDVTATVESVPLIASSIMSKKLAAGARSIVLDVKVGRGAFMKTLEEARLLAKTMVAIGQGAG

RRVRALLTSMEAPLGRAVGNAIEVREAIEALKGEGPGDLLEVALALAEEALRLEGLDPALARKALEGGAALEKFRAFL

EAQGGDPRAVEDFSLLPLAEEHPLRAEREGVVREVDAYKVGLAVLALGGGRKRKGEPIDHGVGVYLLKKPGDRVER

GEALALVYHRRRGLEEALGHLREAYALGEEAHPAPLVLEAI

GtPyNP-T84S was ordered as a synthetic gene from GeneArt (Invitrogen).

MRMVDLIAKKRDGYELSKEEIDFIIRGYTNGDIPDYQMSAFAMAVFFRGMTEEETAALTMAMVRSGDVIDLSKIEG MKVDKHSSGGVGDTTTLVLGPLVASVGVPVAKMSGRGLGHTGGTIDKLESVPGFHVEIDNEQFIELVNKNKIAIIGQ TGNLTPADKKLYALRDVTATVDSIPLIASSIMSKKIAAGADAIVLDVKTGAGAFMKDFAGAKRLATAMVEIGKRVGR KTMAVISDMSQPLGYAVGNALEVKEAIDTLKGKGPEDLQELCLTLGSYMVYLAEKASSLEEARALLEASIREGKALET FKVFLSAQGGDASVVDDPTKLPQAKYRWELEAPEDGYVAEIVADEVGTAAMLLGAGRATKEATIDLSVGLVLHKKV GDAVKKGESLVTIYSNTENIEEVKQKLAKSIRLSSIPVAKPTLIYETIS 


\section{Experimental details and supplementary items}

Wild-type enzymes were cloned as described in previous reports ${ }^{[5,8]}$ and the available glycerol stocks of the enzymes from previous projects ${ }^{[5,9,10]}$ were used directly for this work. BsPyNP was obtained as a freeze-dried enzyme from Sigma Aldrich and dissolved to $1 \mathrm{~g} \mathrm{~L}^{-1}$ in $2 \mathrm{mM}$ phosphate buffer ( $\mathrm{pH} 7$ ).

Cloning of the mutant enzymes was carried out via BamHI/Hindlll sites in the plasmid pGW3 (gift by Matthias Gimpel, unpublished). Codon-optimized genes were obtained (GeneArt Invitrogen/Thermo Fisher Scientific, Massachusetts, USA) and cloned into pGW3 using the recipient strain Escherichia coli DH5 $\alpha$. The correct sequence was confirmed with Sanger Sequencing (LGC Genomics, Berlin, Germany). pGW3 is a $2^{\text {nd }}$ generation derivative of pCTUT7, which was optimized with respect to tightness of the LacO in comparison to the $1^{\text {st }}$ generation derivate used in a previous work. ${ }^{[8]}$

Protein expression and purification was performed as described recently ${ }^{[5,8]}$ in Escherichia coli BL21 using the EnPresso protocol for $50 \mathrm{~mL}$ (Enpresso, Berlin, Germany). Briefly, all enzymes were heterologously expressed in E. coli as $\mathrm{His}_{6}$-tagged proteins through IPTG-induced overexpression. Purification was achieved through cell disruption, heat treatment of the crude extract $\left(80{ }^{\circ} \mathrm{C}\right.$ for TtPyNP, $60^{\circ} \mathrm{C}$ for GtPyNP, both for $30 \mathrm{~min}$; except for EcTP where no heat treatment was performed) and Ni-NTA affinity chromatography. Proteins were eluted with buffer containing $250 \mathrm{mM}$ imidazole, $50 \mathrm{mM}$ sodium phosphate, $300 \mathrm{mM} \mathrm{NaCl}(\mathrm{pH} 8)$ and stored as stock solutions at $-20^{\circ} \mathrm{C}$ in $50 \%(\mathrm{v} / \mathrm{v})$ glycerol. Except for TtPyNP, all proteins were stored in elution buffer with 50\% (v/v) glycerol. TtPyNP was subjected to gel filtration using a PD-10 desalting column to remove the phosphate from the purification process and stored in $10 \mathrm{mM}$ MOPS buffer with $50 \%(\mathrm{v} / \mathrm{v})$ glycerol. Typical protein stock concentrations were around $1 \mathrm{~g} \mathrm{~L}^{-1}$ (calculated with $1 \mathrm{AU} \mathrm{cm}^{-1}$ at $280 \mathrm{~nm}$ being equal to a protein concentration of $\left.1 \mathrm{~g} \mathrm{~L}^{-1}\right)$. Under these storage conditions, no decay of activity could be detected over the course of more than 1.5 years.

Enzymatic phosphorolysis reactions were performed in $200 \mu \mathrm{L}$ PCR tubes and prepared from stock solutions of nucleoside, potassium phosphate and buffer. Typical reaction volumes were $50-150 \mu \mathrm{L}$, depending on the experiment and substrate concentration. Reactions were preheated to the respective temperature for $30 \mathrm{~s}$ and initiated by the addition of 2-10 $\mu \mathrm{L}$ suitably diluted enzyme stock solution (predilution in $10 \mathrm{mM}$ MOPS buffer, $\mathrm{pH}$ 7). Samples were withdrawn at timely intervals after reaction initiation, as detailed in the metadata files freely available online. ${ }^{[2]}$ 
Reaction monitoring of phosphorolysis reactions was achieved via spectral unmixing. From live reactions, samples were withdrawn and quenched in $100 \mathrm{mM}$ aqueous $\mathrm{NaOH}$ as described previously. ${ }^{[5,6]}$ Sample dilution factor was adjusted to reach final concentrations of 100-200 $\mu$ M UVactive reaction components (please note that the exact concentration is not relevant here since spectral unmixing only takes spectral shape and not absolute intensity into account). For instance, from reactions with $1 \mathrm{mM} \mathrm{1a} 50 \mu \mathrm{L}$ of the reaction mixture were pipetted into $250 \mu \mathrm{L} 100 \mathrm{mM} \mathrm{NaOH}$ for quenching and dilution. Of the diluted alkaline sample, $200 \mu \mathrm{L}$ were transferred to UV/Vis-transparent 96-well plates (UV star, GreinerBioOne, Kremsmünster, Austria) for analysis. UV absorption spectra were recorded from 250-350 nm with a BioTek PowerWave HT platereader and subjected to spectral unmixing using analogously obtained reference spectra of $\mathbf{1 a}$ and $\mathbf{2 a}{ }^{[2]}$ Reference spectra used in this study are freely available from the externally hosted Supplementary Information. ${ }^{[2]}$ The degree of conversion was determined directly from the spectral fit which considers the UV-active substrate and product in relation to one another ${ }^{[5]}$ For activity determination, only sampling points showing $3-10 \%$ conversion of the nucleoside substrate were considered. This lower bound was set due to the inherent inaccuracy of the UV-based method employed (roughly \pm 0.3 percentage points, due to the inherent error in spectral acquisition, as described in the original publication $)^{[5]}$ and the upper bound was applied as recommended by Cornish-Bowden ${ }^{[11]}$ for equilibrium reactions. All datapoints outside this window were not included for calculation of activity and marked accordingly in the datasets available in the Supplementary Information. ${ }^{[2]}$ Datapoints that displayed baseline shifts or other spectral anomalies were also excluded from consideration. Background correction was performed as described recently. ${ }^{[6]}$ Experimental spectra were fitted either across the entire spectrum or over one of the information-rich shoulder regions of pyrimidine nucleosides/nucleobases, as appropriate for the analysis. All background corrections and the corresponding datafiles are detailed in the metadata files in the externally hosted supplementary information. ${ }^{[2]}$

Enzymatic activity was determined by linear approximation of the conversion over time with a forced intercept at the origin. All raw data and the datapoints considered for calculation are freely available online with outliers and excluded datapoints clearly marked. ${ }^{[2]}$ The observed rate constant $k_{o b s}$ was obtained by considering the degree of conversion (mol per second) per mol enzyme applied, using the molar extinction coefficient of TtPyNP of $26,930 \mathrm{~cm}^{-1} \mathrm{M}^{-1}$ as predicted by Protparam ${ }^{[12]}$ (i.e. the stock solution of $1 \mathrm{~g} \mathrm{~L}^{-1}$ had a concentration of $\left.37.1 \mu \mathrm{M}\right)$.

Enzyme screening (Figure 1A) was performed using reaction mixtures of $1 \mathrm{mM} \mathrm{1a}, 20 \mathrm{mM}$ potassium phosphate and $30 \mathrm{mg} \mathrm{mL}^{-1}$ enzyme (TtPyNP, GtPyNP, BsPyNP or EcTP) at $50{ }^{\circ} \mathrm{C}$ in $50 \mathrm{mM}$ MOPS buffer $\mathrm{pH} 7$ in a final volume of $50 \mu \mathrm{L}$. These reactions were carried out at a neutral $\mathrm{pH}$ in this buffer system 
to accommodate for the working space of the enzymes used. Later reactions were performed at $\mathrm{pH} 9$ since TtPyNP retains excellent activity and stability under alkaline conditions ${ }^{[9]}$ and pentose-1phosphates (such as $\mathbf{3}$ ) are much more resistant to hydrolysis under alkaline conditions. ${ }^{[13,14]}$ The reactions were quenched by addition of $250 \mu \mathrm{L} 100 \mathrm{mM} \mathrm{NaOH}$ to the reaction mixtures after $30 \mathrm{~min}$. The resulting samples were analyzed by UV spectroscopy as described above. For each protein, control reactions with uridine were performed under identical conditions, all of which gave conversion of the nucleoside to or near equilibrium (Figure S1), confirming that even the moderately thermostable PyNPs from E. coli and B. subtilis are active and stable at $50{ }^{\circ} \mathrm{C}$. For both uridine and $1 \mathrm{a}$, control reactions without protein were carried out, which resulted in no conversion of the starting material.
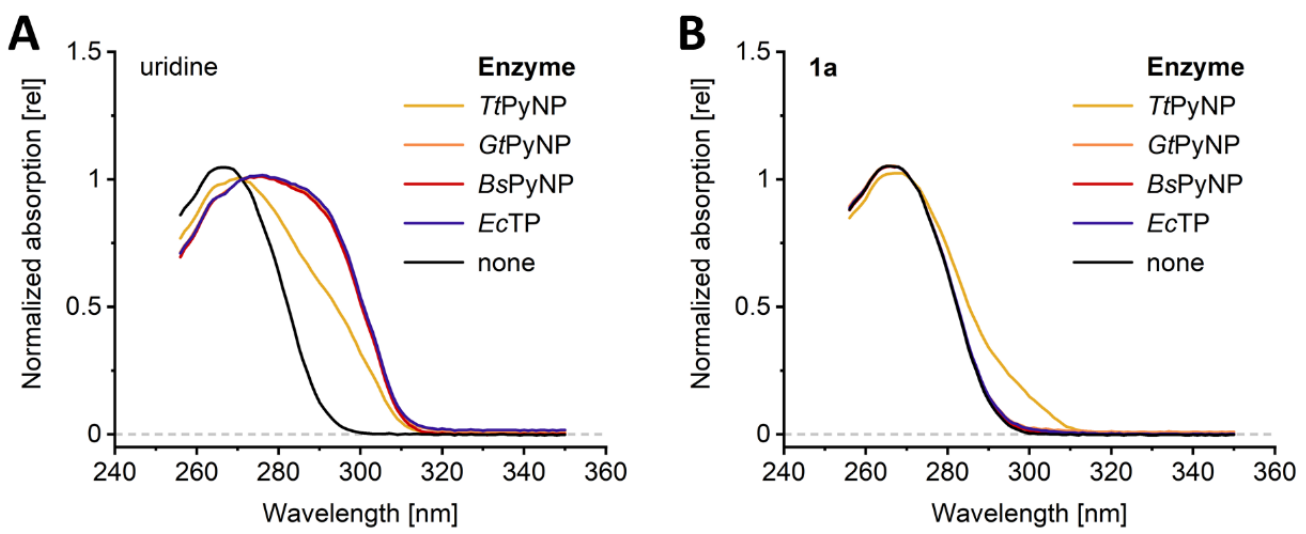

Figure S1. UV spectra obtained from enzyme screening reactions. All enzyme preparations are active with uridine and effected equilibrium conversion of the substrate (A), except for TtPyNP which displays only submaximal activity at $50{ }^{\circ} \mathrm{C} \cdot{ }^{[9]}$ Only TtPyNP displayed appreciable activity with $1 \mathbf{1 a}$ (B). The raw data are available online. ${ }^{[2]}$ For illustrative purposes, all UV spectra shown here were background corrected and normalized to the isosbestic point of base cleavage (271 $\mathrm{nm}$ for this substrate). ${ }^{[6]}$

The control reactions for TtPyNP (Figure 1A) were performed with standard reaction mixtures of $1 \mathrm{mM}$ 1a, $20 \mathrm{mM}$ potassium phosphate and $26.9 \mu \mathrm{gL}^{-1} \mathrm{TtPyNP}(1 \mu \mathrm{M}, 1 \mathrm{~mol} \%)$ at $60{ }^{\circ} \mathrm{C}$ in $50 \mathrm{mM}$ MOPS buffer $\mathrm{pH} 7$ in a final volume of $60 \mu \mathrm{L}$. For the reaction without enzyme, the TtPyNP volume was replaced with water. For the reaction without phosphate, the phosphate volume was replaced with water. For the reaction with boiled enzyme, TtPyNP was subjected to $100^{\circ} \mathrm{C}$ in the reaction mixture in the PCR tube with lid heating $\left(105^{\circ} \mathrm{C}\right)$ for 20 min to denature the protein (TtPyNP has a half-life of $2.3 \mathrm{~min}$ at $\left.100^{\circ} \mathrm{C}\right)^{[9]}$ prior to addition of $1 \mathrm{a}$. The reaction at $\mathrm{pH} 3$ was carried out in a buffer mix consisting of $5 \mathrm{mM}$ citrate, $10 \mathrm{mM}$ MOPS and $20 \mathrm{mM}$ glycine (all final concentration) adjusted to $\mathrm{pH} 3$. The reaction at pH 12 was carried out with $25 \mathrm{mM} \mathrm{NaOH}$ instead of MOPS buffer. All reactions were quenched through addition of $200 \mu \mathrm{L} 100 \mathrm{mM} \mathrm{NaOH}$ and analyzed as described above. 
The NMR spectra of the sugar phosphate 3 (Figure 1B) were recorded directly from a reaction mixture. To this end, a reaction mixture containing $16 \mathrm{mM} 1 \mathrm{a}, 83 \mathrm{mM}$ potassium phosphate $(\mathrm{pH} 7), 100 \mu \mathrm{mL}^{-1}$ (3.71 $\mu \mathrm{M}, 0.02 \mathrm{~mol} \%)$ TtPyNP, approximately $5 \mathrm{mM}$ imidazole, 5\% (v/v) glycerol, 10\% $\mathrm{D}_{2} \mathrm{O}$ with DDS was prepared in a total volume of $500 \mu \mathrm{L}$. Prior to the reaction, ${ }^{1} \mathrm{H}$ (with and without water suppression) and ${ }^{31} \mathrm{P}$ spectra were recorded. The solution was then heated to $70{ }^{\circ} \mathrm{C}$ in the NMR tube for $1.5 \mathrm{~h}$ before analysis of the reaction products. For the assignment of the signals, the following spectra were used: ${ }^{1} \mathrm{H}, \mathrm{H}, \mathrm{H}-\mathrm{COSY}, \mathrm{H}, \mathrm{H}-\mathrm{NOESY},{ }^{1} \mathrm{H}-1 \mathrm{D}-\mathrm{TOCSY},{ }^{13} \mathrm{C}\left\{{ }^{1} \mathrm{H}\right\}, \mathrm{H}, \mathrm{C}-\mathrm{HSQC}, \mathrm{H}, \mathrm{C}-\mathrm{HMBC},{ }^{31} \mathrm{P}, \mathrm{H}, \mathrm{P}-$ HMQC. Solvent suppression was used to suppress the water signal for the ${ }^{1} \mathrm{H}, \mathrm{H}, \mathrm{H}-\mathrm{COSY}$ and $\mathrm{H}, \mathrm{H}-\mathrm{NOSY}$ experiments. The following data were obtained for the reaction components and are shown below in Figures S10-S14. All raw spectra are available from the externally hosted Supplementary Information. ${ }^{[2]}$

$1 a$

${ }^{1} \mathrm{H}$ NMR $\left(700 \mathrm{MHz}, \mathrm{H}_{2} \mathrm{O} / \mathrm{D}_{2} \mathrm{O}\right): \delta=7.88\left(\mathrm{~d},{ }^{3} J_{5,6}=8.4 \mathrm{~Hz}, 1 \mathrm{H} ; \mathrm{H}-6\right), 5.98\left(\mathrm{~d},{ }^{3} \mathrm{~J}_{1^{\prime}, 2}=6.3 \mathrm{~Hz}, 1 \mathrm{H} ; \mathrm{H}^{\prime} 1^{\prime}\right), 5.92(\mathrm{~d}$, $\left.{ }^{3} J_{5,6}=8.4 \mathrm{~Hz}, 1 \mathrm{H} ; \mathrm{H}-5\right), 4.51\left(\mathrm{t}^{3} \mathrm{~J}_{1^{\prime}, 2^{\prime}}={ }^{3} \mathrm{~J}_{2^{\prime}, 3^{\prime}}=6.1 \mathrm{~Hz}, 1 \mathrm{H} ; \mathrm{H}-2^{\prime}\right), 4.22\left(\mathrm{~d},{ }^{3} \mathrm{~J}^{\prime}, 3^{\prime}=5.9 \mathrm{~Hz}, 1 \mathrm{H} ; \mathrm{H}-3^{\prime}\right), 3.63(1 \mathrm{H}, \mathrm{H}-$ $\left.5^{\prime}\right), 1.28$ (s, 3H; Me).

A NOE contact between $\mathrm{H}-\mathrm{I}^{\prime}$ and the methyl group could be observed in the $\mathrm{H}, \mathrm{H}-\mathrm{NOESY}$.

${ }^{13} \mathrm{C}$ NMR (175 MHz, H $\left.\mathrm{H}_{2} \mathrm{O} / \mathrm{D}_{2} \mathrm{O}\right): \delta=169.0$ (C-4), 154.8 (C-2), 144.7 (C-6), 105.4 (C-5), 90.8 (C-1'), 90.4 (C$\left.4^{\prime}\right), 76.5\left(\mathrm{C}-2^{\prime}\right), 74.3\left(\mathrm{C}-3^{\prime}\right), 69.1$ (C-5'), 20.2 (Me).

\section{$2 a$}

${ }^{1} \mathrm{H} \mathrm{NMR}\left(700 \mathrm{MHz}, \mathrm{H}_{2} \mathrm{O} / \mathrm{D}_{2} \mathrm{O}\right): \delta=7.54\left(\mathrm{~d},{ }^{3} \mathrm{~J}_{5,6}=7.8 \mathrm{~Hz}, 1 \mathrm{H} ; \mathrm{H}-6\right), 5.81\left(\mathrm{~d},{ }^{3} J_{5,6}=7.8 \mathrm{~Hz}, 1 \mathrm{H} ; \mathrm{H}-5\right)$.

${ }^{13} \mathrm{C} N M R\left(175 \mathrm{MHz}, \mathrm{H}_{2} \mathrm{O} / \mathrm{D}_{2} \mathrm{O}\right): \delta=170.3$ (C-4), 156.1 (C-2), 146.5 (C-6), 103.9 (C-5).

3

${ }^{1} \mathrm{H}$ NMR $\left(700 \mathrm{MHz}, \mathrm{H}_{2} \mathrm{O} / \mathrm{D}_{2} \mathrm{O}\right): \delta=5.57\left(\mathrm{dd},{ }^{3} \mathrm{~J}_{\mathrm{H}, P}=6.6 \mathrm{~Hz},{ }^{3} J_{1,2}=4.2 \mathrm{~Hz}, 1 \mathrm{H} ; \mathrm{H}-1\right), 4.23\left(\mathrm{dd},{ }^{3} J_{2,3}=6.1 \mathrm{~Hz}\right.$, $\left.{ }^{3} J_{1,2}=4.2 \mathrm{~Hz}, 1 \mathrm{H} ; \mathrm{H}-2\right), 4.00\left(\mathrm{~d},{ }^{3} J_{2,3}=6.1 \mathrm{~Hz}, 1 \mathrm{H} ; \mathrm{H}-3\right), 3.46(\mathrm{~m}, 1 \mathrm{H} ; \mathrm{H}-5), 1.30(\mathrm{~s}, 3 \mathrm{H} ; \mathrm{Me})$.

A NOE contact between $\mathrm{H}-1$ and the methyl group could not be observed in the $\mathrm{H}, \mathrm{H}-\mathrm{NOESY}$.

${ }^{31} \mathrm{P}$ NMR (203 MHz, $\mathrm{H}_{2} \mathrm{O} / \mathrm{D}_{2} \mathrm{O}$ ): $\delta=1.89$ (determined via $\mathrm{H}, \mathrm{P}-\mathrm{HMQC}$ due to strong overlap with the phosphate buffer).

${ }^{13} \mathrm{C}$ NMR (175 MHz, $\left.\mathrm{H}_{2} \mathrm{O} / \mathrm{D}_{2} \mathrm{O}\right): \delta=100.0\left(\mathrm{~d},{ }^{2} \mathrm{~J}_{C, P}=4.1 \mathrm{~Hz} ; \mathrm{C}-1\right), 89.8$ (C-4), 75.0 (C-2), 74.8 (C-3), 70.0 (C5), 21.5 (Me). 
The Michaelis-Menten-type kinetics of TtPyNP (Figure 1C) were investigated with reactions containing $50 \mathrm{mM}$ potassium phosphate and $12 \mu \mathrm{g} \mathrm{m}^{-1}$ TtPyNP $(0.45 \mu \mathrm{M})$ in $50 \mathrm{mM}$ glycine/ $\mathrm{NaOH}$ buffer $\mathrm{pH} 9$ with 0.5-5 mM 1a. Reaction volumes, sampling times and sampling volumes are indicated in Table S1. Raw data and calculations for this experiment are freely available online ${ }^{[2]}$ The obtained data were fit to the Michaelis-Menten equation according to

$$
k_{o b s, \max }=\frac{k_{o b s}[S]}{K_{M}{ }^{\prime}+[S]}
$$

where $k_{o b s, \max }$ is the maximal observed rate constant $\left[\mathrm{s}^{-1}\right], k_{o b s}$ is the rate constant $\left[\mathrm{s}^{-1}\right]$ observed at the substrate concentration $[S][\mathrm{mM}]$ and $K_{M}{ }^{\prime}$ is the apparent Michaelis-Menten constant [mM]. The fit yielded $k_{\text {obs,max }}=2.54 \pm 0.35 \mathrm{~s}^{-1}$ and $K_{M}{ }^{\prime}=3.37 \pm 0.88 \mathrm{mM}\left(\mathrm{R}^{2}=0.96\right)$. We intentionally termed this an apparent Michaelis-Menten constant since the enzyme is to some extent inhibited by pyrimidine nucleobases, ${ }^{[9]}$ which presents a complicating factor for our kinetic analyses. However, under the conditions probed by us with 1a, TtPyNP did not exhibit any noticeable inhibitory behavior. Therefore, we applied standard Michaelis-Menten fitting.

Table S1. Conditions used for kinetics experiments for $K_{M}$ determination.

\begin{tabular}{ccccc} 
1a $[\mathrm{mM}]$ & Sampling times $[\mathrm{min}]$ & $\begin{array}{c}\text { Reaction volume } \\
{[\mu \mathrm{L}]}\end{array}$ & $\begin{array}{c}\text { Sampling volume } \\
{[\mu \mathrm{L}]}\end{array}$ & $\begin{array}{c}\text { Volume of } \\
\text { quenching NaOH } \\
{[\mu \mathrm{L}]}\end{array}$ \\
0.5 & $1.5,3,4.5$ & 200 & 65 & 150 \\
1 & $2,4,6$ & 150 & 50 & 200 \\
2 & $4,8,12$ & 75 & 25 & 200 \\
5 & $10,20,30$ & 30 & 10 & 200 \\
\hline
\end{tabular}

The temperature-dependence of the activity of TtPyNP with 1a (Figure 1D) was determined using reaction mixtures of $1 \mathrm{mM} \mathrm{1a}$ and $50 \mathrm{mM}$ potassium phosphate in $50 \mathrm{mM}$ glycine/ $\mathrm{NaOH}$ buffer at $\mathrm{pH} 9$ and the indicated temperature in a total volume of $150 \mu \mathrm{L}$. Depending on the temperature (and, therefore, on rate of phosphorolysis), 6-24 $\mu \mathrm{g} \mathrm{mL}^{-1} \mathrm{TtPyNP}$ were used $\left(6 \mu \mathrm{g} \mathrm{mL}^{-1}\right.$ for $70{ }^{\circ} \mathrm{C}, 12 \mu \mathrm{gL}^{-1}$ for $60^{\circ} \mathrm{C}$ and $24 \mu \mathrm{g} \mathrm{m}^{-1}$ for $50^{\circ} \mathrm{C}$ ), to permit sampling of all reactions within the same time domain. From all reactions, samples of $50 \mu \mathrm{L}$ were withdrawn after 2,4 and 6 min, quenched in $300 \mu \mathrm{L} 100 \mathrm{mM}$ $\mathrm{NaOH}$ and analyzed as described above. Raw data and calculations for this experiment are freely available online ${ }^{[2]}$ The obtained data were fit to the Eyring equation. ${ }^{[15]}$

$$
k_{o b s}=\frac{\kappa k_{b} T}{h} \exp \left(-\frac{\Delta_{R} H^{0 \ddagger}-T \Delta_{R} S^{0 \ddagger}}{R T}\right)
$$




$$
\ln \left(\frac{k_{o b s}}{T}\right)=\ln \left(\frac{\kappa k_{b}}{h}\right)-\left(\frac{\Delta_{R} H^{0 \ddagger}}{T}\right)+\left(\frac{\Delta_{R} S^{0 \ddagger}}{R}\right)
$$

where $k_{o b s}$ is the observed rate constant $\left[\mathrm{s}^{-1}\right], \kappa$ is the transmission coefficient (herein assumed to be unity), $k_{b}$ is the Boltzmann constant $\left(1.38 \cdot 10^{-23} \mathrm{~J} \mathrm{~K}^{-1}\right), T$ is the temperature $[\mathrm{K}], h$ is the Planck constant $\left(6.626 \cdot 10^{-34} \mathrm{~J} \mathrm{~s}\right), R$ is the universal gas constant $\left(8.314 \mathrm{~J} \mathrm{~mol}^{-1} \mathrm{~K}^{-1}\right), \Delta_{R} H^{0 \ddagger}$ the transition state enthalpy [J mol$\left.{ }^{-1}\right]$ and $\Delta_{R} S^{0 \ddagger}$ is the transition state entropy [ $\mathrm{J} \mathrm{mol}^{-1} \mathrm{~K}^{-1}$. The fit of the experimental data shown in Figure 1D for 1a yielded $\Delta_{R} H^{0 \ddagger}=99.18 \pm 17.47 \mathrm{~kJ} \mathrm{~mol}^{-1}$ and $\Delta_{R} S^{0 \ddagger}=36.64 \pm 52.49 \mathrm{~J} \mathrm{~mol}^{-1} \mathrm{~K}^{-1}\left(\mathrm{R}^{2}=\right.$ 0.94). The data shown for uridine were taken from our earlier report ${ }^{[9]}$ and the fit shown in Figure $1 D$ gave $\Delta_{R} H^{0 \ddagger}=101.55 \pm 2.53 \mathrm{~kJ} \mathrm{~mol}^{-1}$ and $\Delta_{R} S^{0 \ddagger}=72.18 \pm 7.59 \mathrm{~J} \mathrm{~mol}^{-1} \mathrm{~K}^{-1}\left(\mathrm{R}^{2}=0.99\right)$.

The thermodynamic control of the phosphorolysis of 1a (Figure 1E) was probed with reaction mixtures of $1 \mathrm{mM} 1 \mathrm{a}$ and $100 \mu \mathrm{gL}^{-1}$ TtPyNP $(3.71 \mu \mathrm{M}, 0.37 \mathrm{~mol} \%)$ in $50 \mathrm{mM}$ glycine/ $\mathrm{NaOH}$ buffer at $\mathrm{pH} 9$ and $60{ }^{\circ} \mathrm{C}$ in a total volume of $160 \mu \mathrm{L}$ with either $2,5,10$ or $20 \mathrm{mM}$ potassium phosphate (equivalent to 2 , $5,10$ or 20 equivalents of phosphate over the nucleoside $1 \mathrm{a})$. The reaction mixtures were incubated in a PCR cycler with lid heating $\left(70^{\circ} \mathrm{C}\right)$. Samples of $25 \mu \mathrm{L}$ were quenched in $225 \mu \mathrm{L} 100 \mathrm{mM} \mathrm{NaOH}$ after $2,8,30,60,111$ and 165 min and analyzed by spectral unmixing as described above and in the metadata files available online. ${ }^{[2]}$ Likewise, the raw data for this experiment are freely available in the externally hosted supplementary information..$^{[2]}$ The obtained data were fit to equation (S4) which was derived as detailed below.

$$
c=\frac{-K-K x+\sqrt{(K+K x)^{2}+4 K x(1-K)}}{2(1-K)}
$$

where $c$ is the extent of conversion in the equilibrium (in fractions, not \%), $K$ is the equilibrium constant of phosphorolysis and $x$ is the excess of phosphate (i.e. equivalents of phosphate over the nucleoside substrate). All these variables are dimensionless. The fit of the experimental data yielded $K=0.1605$ $\pm 0.0056\left(R^{2}=0.99\right)$ for $c=0.395,0.55,0.7$ and 0.79 for $2,5,10$ or 20 equivalents of phosphate, respectively. For simplicity's sake, we performed all further calculations building on this equilibrium constant with $K=0.16$.

Derivation of equation (S4) for the determination of phosphorolysis equilibrium constants from phosphorolysis equilibria with different phosphate excesses:

Nucleoside phosphorolysis is a thermodynamically controlled reaction which closely adheres to the law of mass action. ${ }^{[10]}$

$$
K=\frac{[B][P 1 P]}{[N][P]}
$$

where $[B],[P 1 P],[N]$ and $[P]$ are the equilibrium concentration of the nucleobase (2a in this case), pentose-1-phosphate ( $\mathbf{3}$ in this case), nucleoside (1a in this case) and orthophosphate (all in an 
arbitrary molar concentration), respectively. Herein, we assume that stoichiometry holds true (S6), as do the mass balances of all components in this system (S7-S9).

$$
\begin{gathered}
{[B]=[P 1 P]} \\
{[N]=[N]_{0}-[B]} \\
{[P]=[P]_{0}-[B]} \\
{[B]=c[N]_{0}}
\end{gathered}
$$

where $[N]_{0}$ is the initial nucleoside concentration and $[P]_{0}$ is the initial phosphate concentration. The initial concentrations of the products (nucleobase and pentose-1-phosphate) are regarded as zero. In a scenario where the phosphate concentration is expressed as a function of the nucleoside concentration, the following equations (S10-S12) can be formulated.

$$
\begin{gathered}
x=\frac{[P]_{0}}{[N]_{0}} \\
{[N]_{0}=\frac{[P]_{0}}{x}=1} \\
{[P]_{0}=x[N]_{0}=x}
\end{gathered}
$$

Substitution of equations (S6), (S9), (S11) and (S12) in the law of mass action (S5) then gives a simplified equation with variables that are either easily accessible experimentally or known from the experimental setup.

$$
K=\frac{\left(c[N]_{0}\right)^{2}}{\left([N]_{0}-c[N]_{0}\right)\left([P]_{0}-c[N]_{0}\right)}=\frac{c^{2}}{(1-c)(x-c)}
$$

This quadratic equation can be rewritten to equation (S14) and solved via equations (S15) and (S16).

$$
\begin{aligned}
c^{2}= & K(1-c)(x-c)=x K-c K-c x K+K c^{2} \\
& (1-K) c^{2}+(K+K x) c-x K=0 \\
c_{1,2}= & \frac{-K-K x \pm \sqrt{(K+K x)^{2}+4 K x(1-K)}}{2(1-K)}
\end{aligned}
$$

Equation (S16) has only one physically reasonable solution, which is equivalent to equation (S4) and returns equilibrium constants of phosphorolysis for experimentally obtained equilibrium conversions $c$ under known phosphate excesses $x$.

The temperature-dependence of the phosphorolysis equilibria of 1a was evaluated using reaction mixtures of $1 \mathrm{mM}$ 1a, $2 \mathrm{mM}$ potassium phosphate, $100 \mu \mathrm{gL}^{-1}$ TtPyNP (3.71 $\mu \mathrm{M}, 0.37 \mathrm{~mol} \%$ ) in $50 \mathrm{mM}$ glycine $/ \mathrm{NaOH}$ buffer at $\mathrm{pH} 9$ in a total volume of $150 \mu \mathrm{L}$. The mixtures were incubated at $75^{\circ} \mathrm{C}$ or $90^{\circ} \mathrm{C}$ until the respective equilibria were reached and samples of $50 \mu \mathrm{L}$ were taken after 30,45 and $60 \mathrm{~min}$ and quenched in $200 \mu \mathrm{L} 100 \mathrm{mM} \mathrm{NaOH}$. The resulting alkaline samples were analyzed by spectral unmixing as described above. The obtained conversion data was transformed to equilibrium constants using equations (S5)-(S8) and fitted in an Arrhenius fashion to equation (S17). ${ }^{[10]}$ 


$$
K=e^{-\frac{\Delta_{R} H^{0 \prime}-T \Delta_{R} S^{0 \prime}}{R T}}
$$

where $\Delta_{R} H^{\prime}$ is the apparent reaction enthalpy of phosphorolysis [ $\mathrm{J} \mathrm{mol}^{-1}$ ], $\Delta_{R} S^{\prime}$ is the apparent reaction entropy of phosphorolysis $\left[\mathrm{J} \mathrm{mol}^{-1} \mathrm{~K}^{-1}\right], R$ is the universal gas constant $\left(8.314 \mathrm{~J} \mathrm{~mol}^{-1} \mathrm{~K}^{-1}\right)$ and $T$ is the temperature [K]. The fit yielded $\Delta_{R} H^{\prime}=8.88 \pm 0.90 \mathrm{~kJ} \mathrm{~mol}^{-1}$ and $\Delta_{R} S^{\prime}=11.66 \pm 2.56 \mathrm{~J} \mathrm{~mol}^{-1} \mathrm{~K}^{-1}$ $\left(R^{2}=0.93\right)$. The raw data for this experiment are available from the externally hosted Supplementary Information. ${ }^{[2]}$

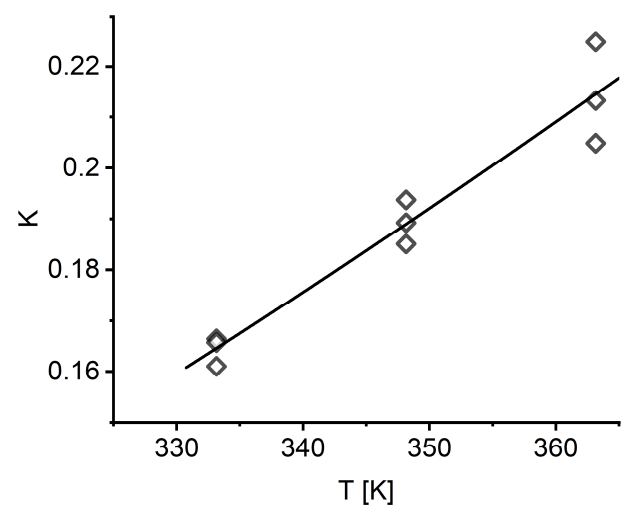

Figure S2. Temperature-dependence of $K_{1 a}$. Data for 60,75 and $90{ }^{\circ} \mathrm{C}$ were used for calculation.

The activity of the mutant PyNPs (Table S2, see below) was assessed with reaction mixtures of $1 \mathrm{mM}$ 1a and $50 \mathrm{mM}$ potassium phosphate in $50 \mathrm{mM}$ glycine buffer $\mathrm{pH} 9$ with PyNP $\left(8 \mu \mathrm{gL}^{-1}\right.$ TtPyNP-S83T, $\left.30 \mu \mathrm{g} \mathrm{mL}{ }^{-1} \mathrm{GtPyNP}-\mathrm{T} 84 \mathrm{~S}\right)$ at $60^{\circ} \mathrm{C}$ in a total volume of $150 \mu \mathrm{L}$. Samples of $50 \mu \mathrm{L}$ were taken after 20,40 and $60 \mathrm{~min}$, quenched in $300 \mu \mathrm{L} 100 \mathrm{mM} \mathrm{NaOH}$ and analyzed by spectral unmixing. Kinetic constants were calculated as described above, using the extinction coefficient of $21,890 \mathrm{~cm}^{-1} \mathrm{M}^{-1}$ of GtPyNP. The raw data and calculations for this experiment are available online. ${ }^{[2]}$

Table S2. Phosphorolytic activity of wild-type (wt) enzymes and mutants with $\mathbf{1 a} .^{\text {[a] }}$

$\begin{array}{ccc}\text { Enzyme } & k_{o b s}\left[\mathrm{~s}^{-1}\right] & \text { Activity }\left[\mathrm{U} \mathrm{mg}^{-1}\right]^{[\mathrm{b}]} \\ \text { TtPyNP wt } & 0.59 & 1.31 \\ \text { TtPyNP-S83T } & 0.25 & 0.55 \\ \text { GtPyNP wt } & - & - \\ \text { GtPyNP-T84S } & 0.02 & 0.05\end{array}$

[a] Reactions conditions are detailed in the paragraph above, [b] one unit (U) of activity is defined as the conversion of $1 \mu \mathrm{mol}$ of $\mathbf{1} \mathbf{a}$ to $\mathbf{2 a}$ per minute under the conditions detailed above. 
The thermodynamic control of the phosphorolysis of other methylated nucleosides (Figure 3) was determined via transglycosylation using reaction mixtures of $0.25 \mathrm{mM}$ nucleobase (2b-2k), $0.075 \mathrm{mM}$ potassium phosphate (0.3 equivalents), $50 \mu \mathrm{g} \mathrm{mL}^{-1} \operatorname{TtPyNP}(1.85 \mu \mathrm{M}, 0.7 \mathrm{~mol} \%$ with respect to the nucleobase) in $20 \mathrm{mM}$ glycine buffer pH 9 at $60^{\circ} \mathrm{C}$ with either $0.125 \mathrm{mM}$ (0.5 eq.), $0.25 \mathrm{mM}$ (1 eq.), 0.5 (2 eq.) or $1 \mathrm{mM}$ (4 eq.) 1a in a total volume of $50 \mu \mathrm{L}$. Reaction mixtures with purine nucleobases $(\mathbf{2 g}-\mathbf{2 k})$ additionally contained $125 \mathrm{\mu g} \mathrm{mL}^{-1}$ of the purine nucleoside phosphorylase from Geobacillus thermoglucosidasius. The reaction mixtures were incubated in a PCR cycler with lid heating $\left(70^{\circ} \mathrm{C}\right)$ for $4 \mathrm{~h}$. This reaction time was chosen based on initial experiments. The time to equilibrium was approximated by UV spectroscopy and the reaction was then run for twice this time before quenching. After the reaction, the mixtures were quenched through addition of $50 \mu \mathrm{L} \mathrm{MeOH}$, centrifuged (13,000 rpm, $10 \mathrm{~min})$ and analyzed by HPLC. Conversion was calculated according to equation (S18), which assumes that the molar extinction coefficients of the nucleobase $\mathbf{2}$ and the corresponding nucleoside 1 are equal.

$$
c_{T}=100 \frac{P_{\mathbf{1}}}{P_{\mathbf{1}}+P_{\mathbf{2}}}
$$

where $c_{T}$ is the conversion in the transglycosylation reaction (i.e. conversion of the nucleobase to the target nucleoside), $P_{\mathbf{1}}$ is the peak area of the target nucleoside (1) and $P_{\mathbf{2}}$ is the peak area of the nucleobase (2). Typical retention times of the compounds used herein are given in Table S3. The identity of all target compounds was confirmed by high-resolution mass spectrometry (HRMS) as detailed below in Table S4. The raw data for all HPLC runs used for calculation of equilibrium constants are freely available online. ${ }^{[2]}$ Since opening and processing of the files requires Agilent software, all chromatograms are depicted below (Figure S3) and integration results are listed in Table S3. The equilibrium constants of phosphorolysis of the target nucleoside were determined by fitting the conversion of the nucleobase to the corresponding nucleoside as a function of the excess of $1 \mathbf{a}$ according to equation (S19), which is derived below.

$$
c_{T}=100 \frac{K_{N}(z+1)-\sqrt{K_{N}\left(K_{N} z^{2}-2 K_{N} z+K_{N}+4 z\right)}}{2\left(K_{N}-1\right)}
$$

where $K_{N}$ is the net equilibrium constant of transglycosylation as given by equation (S20) and $z$ is the excess of 1a over the nucleobase $\mathbf{2}$ as given by equation (S21).

$$
\begin{gathered}
K_{N}=\frac{K_{1}}{K_{2}} \\
z=\frac{[B]_{2,0}}{[N]_{1,0}}
\end{gathered}
$$

where $K_{1}$ and $K_{2}$ are the equilibrium constants of phosphorolysis of the donor (1a) and acceptor nucleoside (1/b-1k), $[B]_{2,0}$ is the initial concentration of the nucleobase $2[\mathrm{mM}]$ and $[N]_{1,0}$ the initial 
concentration of the donor $1 \mathrm{a}[\mathrm{mM}]$. The equilibrium constants of phosphorolysis of the target nucleosides $\left(K_{2}\right)$ were then obtained by employing equation (S20), using $K_{1}=K_{1 a}=0.16$.

Derivation of equation (S19) for the determination of phosphorolysis equilibrium constants from transglycosylation equilibria with different excesses of the donor nucleoside:

Nucleoside transglycosylation comprises a phosphorolysis reaction followed by reverse phosphorolysis (also termed glycosylation) reaction to transfer the sugar moiety from one nucleoside to another. Herein, both elementary steps constitute separate enzymatic steps that proceed according to their individual equilibrium constants of phosphorolysis, which dictate the maximum extent of conversion in these reactions. Therefore, conversions in transglycosylation reactions are a function of the thermodynamic properties of the starting material and product nucleoside, which allows yield prediction for transglycosylation reactions via examination of phosphorolysis thermodynamics. Conversely, transglycosylation reactions can be used to determine equilibrium constants of phosphorolysis, which we exploited in this work. When one equilibrium constant (the one of the sugar donor, 1a) has been determined from phosphorolysis experiments, transglycosylation reactions can be used to accurately determine the equilibrium constant of phosphorolysis of the product nucleoside (the sugar acceptor), which undergoes a reverse phosphorolysis. Calculation of conversion and application of equation (S19) then yields equilibrium constants of phosphorolysis for a diverse set of products.

The basis for equation (S19) is given by an expression reported and derived in our previous report (equation (4) in the original paper). ${ }^{[16]}$

$$
\begin{gathered}
c_{T}=100 \frac{K_{N}\left([N]_{1,0}+[B]_{2,0}\right)}{2\left(K_{N}-1\right)}- \\
\frac{\sqrt{K_{N}\left(K_{N}[N]_{1,0}^{2}-2 K_{N}[N]_{1,0}[B]_{2,0}+K_{N}[B]_{2,0}^{2}+4[N]_{1,0}[B]_{2,0}\right)}}{2\left(K_{N}-1\right)}
\end{gathered}
$$

with definitions from above. Equation (S19) can be obtained from this expression by substituting $[N]_{1,0}$ and $[B]_{2,0}$ according to equations (S23) and (S24), which are consequences of equation (S21).

$$
\begin{aligned}
& {[N]_{1,0}=z} \\
& {[B]_{2,0}=1}
\end{aligned}
$$

It should be noted that equation (S22), and in turn also (S19), inherently builds on the assumption of an ideal transglycosylation - i.e. a process during which no transglycosylation intermediate (pentose1-phosphate, $\mathbf{3}$ in this case) contributes to the mass balance of the donor and target nucleoside. This in turn necessitates the assumption of a net zero phosphate concentration $([P 1 P]=[P]=0)$, which is, of course, unrealistic. However, the observed deviation of the real conversions from those expected in an ideal case is almost imperceptibly small for low phosphate concentrations. For instance, we 
employed 0.3 equivalents of phosphate, which causes roughly a $0.2-0.5 \%$ deviation of the real (experimental) conversion from the ideal case, depending on the equilibrium constant of the target nucleoside $\left(K_{2}\right.$; as described in a previous work). ${ }^{[16]}$ Since this deviation is well within the inherent error of HPLC, equation (S19) provides an accurate output for realistic experimental data.

Table S3. HPLC data for determination of equilibrium constants of phosphorolysis. ${ }^{[a]}$

\begin{tabular}{|c|c|c|c|c|c|c|c|c|c|}
\hline Entry & $\begin{array}{l}\text { Excess } Z \\
\text { [x-fold }]\end{array}$ & $\begin{array}{l}\text { Nucleo- } \\
\text { base } 2\end{array}$ & $\begin{array}{c}\text { Ret. } \\
\text { time } 2 \\
\text { [min] }\end{array}$ & $\begin{array}{c}\text { Peak } \\
\text { area } 2 \\
\text { [mAUs] }\end{array}$ & $\begin{array}{c}\text { Ret. } \\
\text { time } 1 \\
\text { [min] }\end{array}$ & $\begin{array}{c}\text { Peak } \\
\text { area } 1 \\
\text { [mAUs] }\end{array}$ & $\begin{array}{l}\text { Conv. } \\
2 \text { to } 1 \\
{[\%]}\end{array}$ & $K_{N}$ & $K_{i}$ \\
\hline 1 & 0.5 & \multirow{4}{*}{$2 b$} & \multirow{4}{*}{4.5} & 389 & \multirow{4}{*}{10.9} & 190 & 32.8 & \multirow{4}{*}{1.28} & \multirow{4}{*}{0.12} \\
\hline 2 & 1 & & & 318 & & 349 & 52.3 & & \\
\hline 3 & 2 & & & 199 & & 493 & 71.2 & & \\
\hline 4 & 4 & & & 112 & & 587 & 84.0 & & \\
\hline 5 & 0.5 & \multirow{4}{*}{$2 c$} & \multirow{4}{*}{3.2} & 418 & \multirow{4}{*}{8.8} & 150 & 26.4 & \multirow{4}{*}{1.30} & \multirow{4}{*}{0.12} \\
\hline 6 & 1 & & & 287 & & 284 & 49.7 & & \\
\hline 7 & 2 & & & 141 & & 429 & 75.3 & & \\
\hline 8 & 4 & & & 77 & & 503 & 86.7 & & \\
\hline 9 & 0.5 & \multirow{4}{*}{$2 d$} & \multirow{4}{*}{5.2} & 225 & \multirow{4}{*}{12.4} & 82 & 26.7 & \multirow{4}{*}{0.76} & \multirow{4}{*}{0.21} \\
\hline 10 & 1 & & & 175 & & 147 & 45.7 & & \\
\hline 11 & 2 & & & 120 & & 219 & 64.6 & & \\
\hline 12 & 4 & & & 74.8 & & 263 & 77.9 & & \\
\hline 13 & 0.5 & \multirow{4}{*}{$2 e$} & \multirow{4}{*}{7.8} & 282 & \multirow{4}{*}{13.6} & 55 & 16.3 & \multirow{4}{*}{0.22} & \multirow{4}{*}{0.73} \\
\hline 14 & 1 & & & 225 & & 111 & 33.0 & & \\
\hline 15 & 2 & & & 189 & & 139 & 42.4 & & \\
\hline 16 & 4 & & & 131 & & 197 & 60.1 & & \\
\hline 17 & 0.5 & \multirow{4}{*}{$2 g$} & \multirow{4}{*}{4.8} & 618 & \multirow{4}{*}{12.6} & 415 & 40.2 & \multirow{4}{*}{7.38} & \multirow{4}{*}{0.02} \\
\hline 18 & 1 & & & 297 & & 772 & 72.2 & & \\
\hline 19 & 2 & & & 83 & & 998 & 92.3 & & \\
\hline 20 & 4 & & & 17 & & 1099 & 98.5 & & \\
\hline 21 & 0.5 & \multirow{4}{*}{$2 \mathrm{~h}$} & & 459 & & 433 & 48.5 & & \\
\hline 22 & 1 & & 10.5 & 198 & 15.2 & 720 & 78.4 & 13.78 & 0.01 \\
\hline 23 & 2 & & 10.5 & 61 & & 906 & 93.7 & 0 & 0.01 \\
\hline 24 & 4 & & & 21 & & 948 & 97.8 & & \\
\hline 25 & 0.5 & & & 260 & & 265 & 50.5 & & \\
\hline 26 & 1 & $2 i$ & 3.9 & 146 & 12.0 & 441 & 75.1 & 11.12 & 0.01 \\
\hline 27 & 2 & & & 44 & & 564 & 92.8 & & \\
\hline 28 & 4 & & & 9 & & 660 & 98.7 & & \\
\hline 29 & 0.5 & & & 477 & & 91 & 16.0 & & \\
\hline 30 & 1 & $2 j$ & 3.4 & 472 & 10.9 & 148 & 23.9 & 0.08 & 1.88 \\
\hline 31 & 2 & $2 \mathrm{~J}$ & 3.4 & 434 & 10.9 & 186 & 30.0 & 0.08 & 1.88 \\
\hline 32 & 4 & & & 375 & & 276 & 42.4 & & \\
\hline 33 & 0.5 & & & 472 & & 106 & 18.3 & & \\
\hline 34 & 1 & $2 k$ & 3.2 & 419 & 9.9 & 145 & 25.7 & 0.11 & 1.51 \\
\hline 35 & 2 & $2 \pi$ & 0.2 & 355 & & 182 & 33.9 & 0.11 & 1.5 \\
\hline 36 & 4 & & & 322 & & 256 & 44.3 & & \\
\hline
\end{tabular}

[a] Chromatograms are shown below in Figure S3. 
A

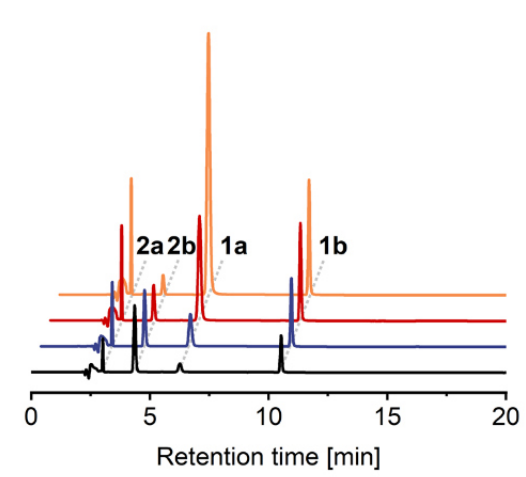

C

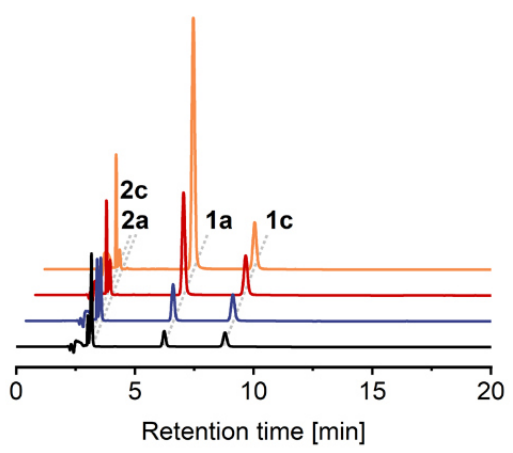

$\mathbf{E}$

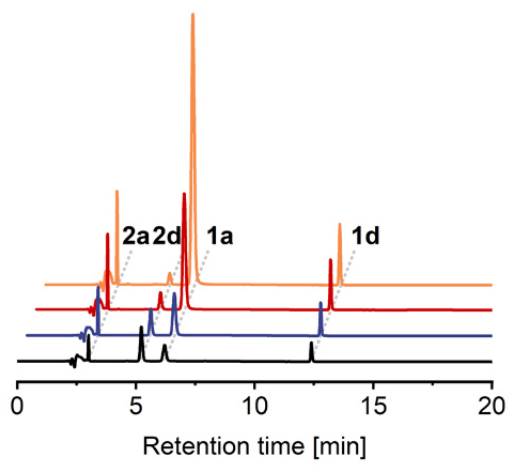

G

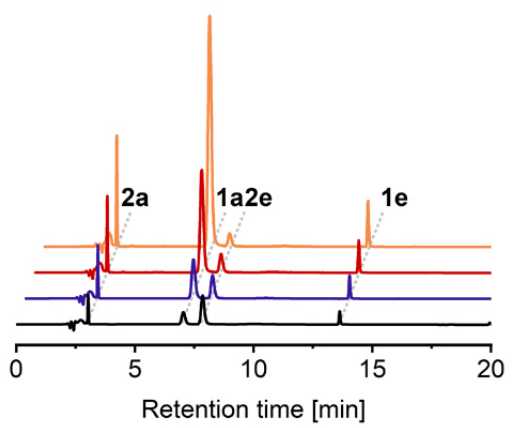

B

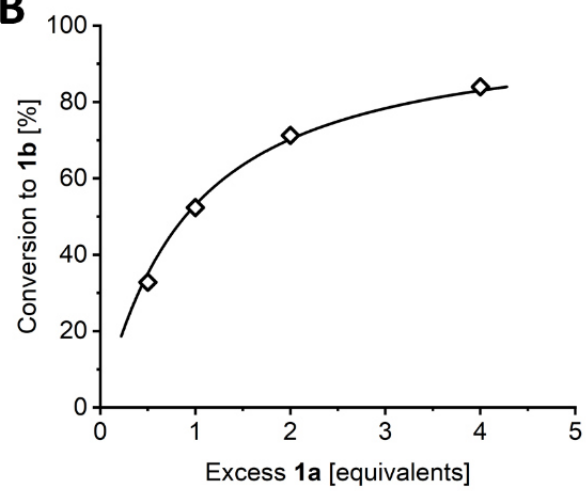

D

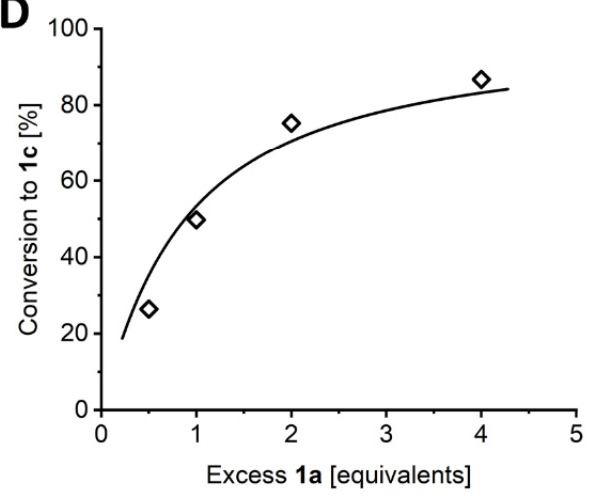

$\mathbf{F}$

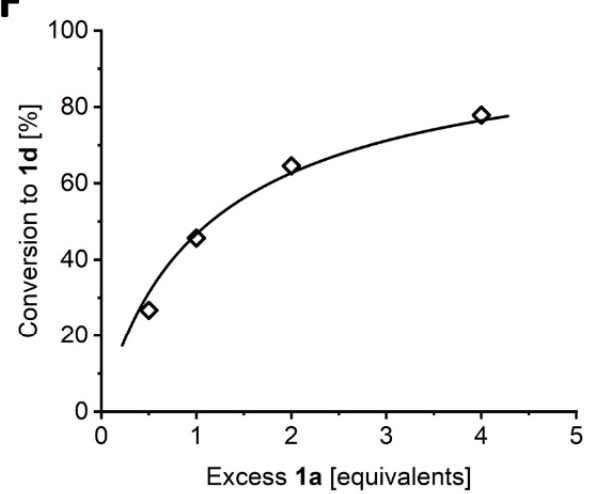

H

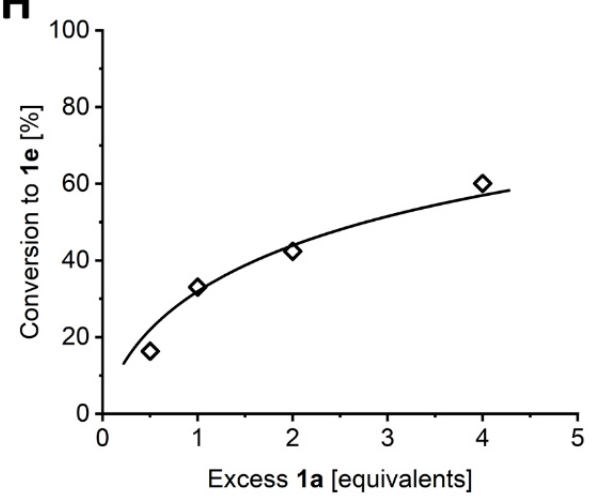

Figure S3. HPLC-DAD data $(260 \mathrm{~nm})$ and fits for the determination of equilibrium constants of phosphorolysis from transglycosylation reactions (see below for full figure legend). 
I

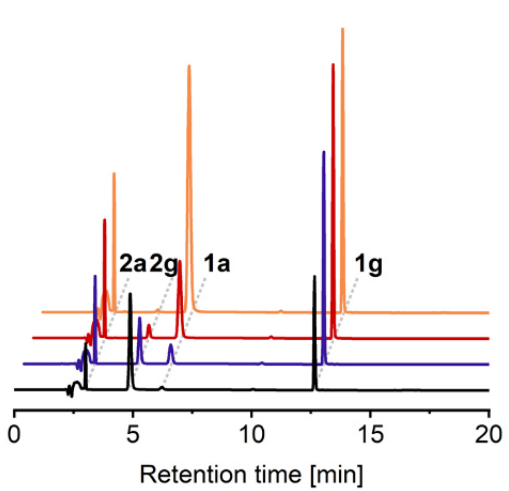

K

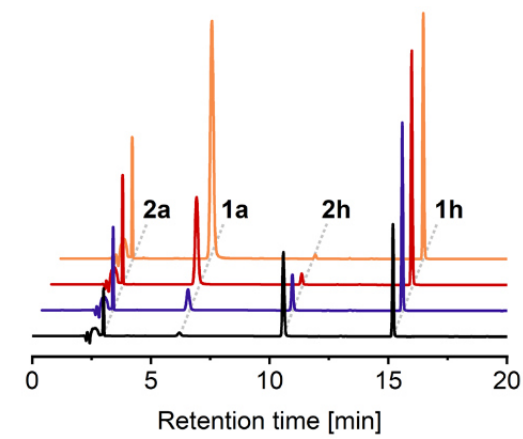

M

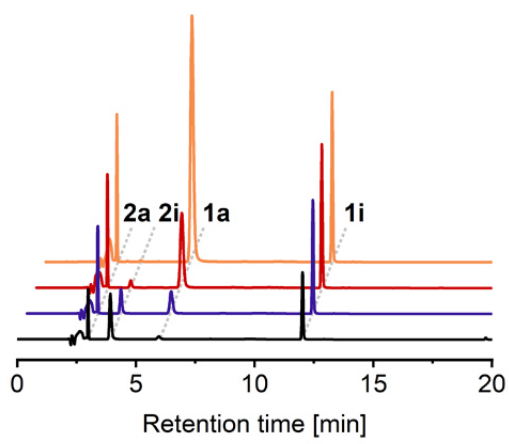

0

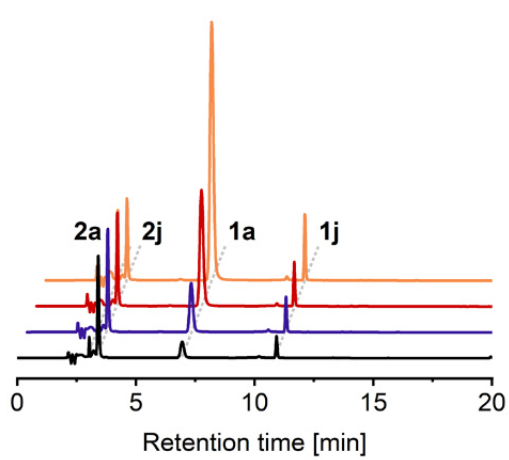

J

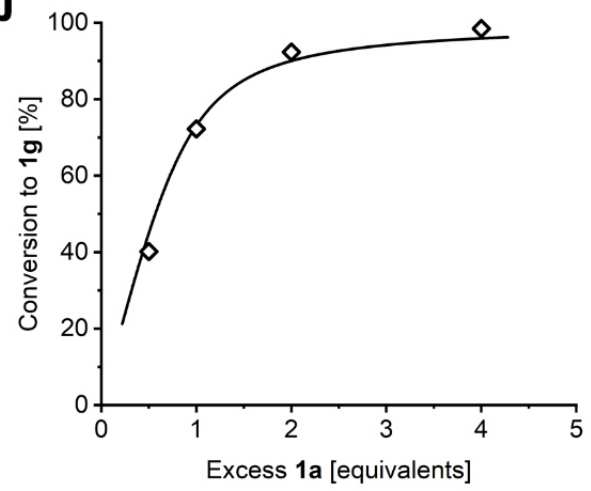

$\mathbf{L}$

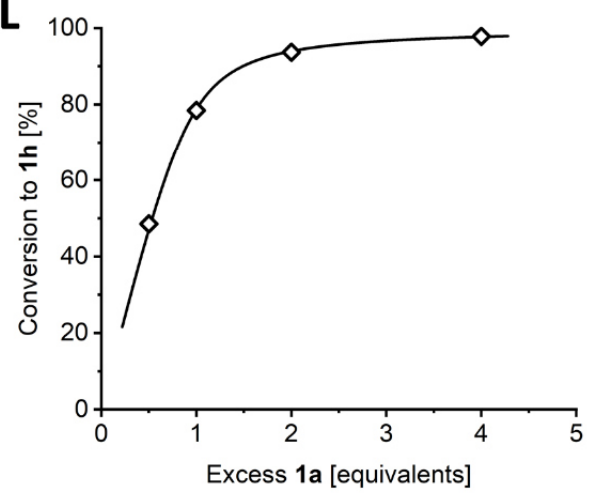

$\mathbf{N}$

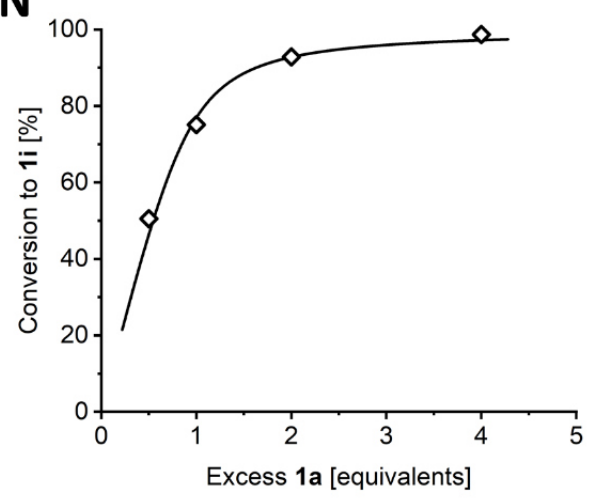

$\mathbf{P}$

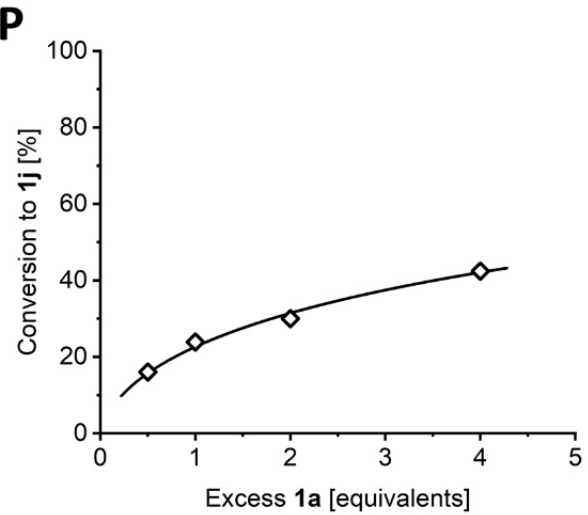

Figure S3 (continued). HPLC-DAD data $(260 \mathrm{~nm})$ and fits for the determination of equilibrium constants of phosphorolysis from transglycosylation reactions (see below for full figure legend). 

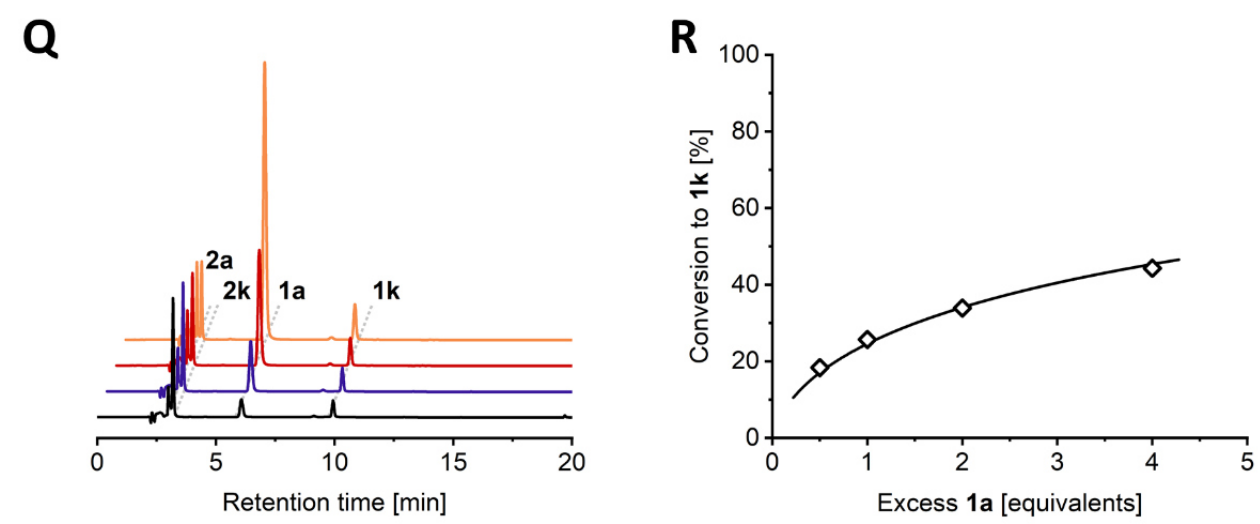

Figure S3 (continued). HPLC-DAD data $(260 \mathrm{~nm})$ and fits for the determination of equilibrium constants of phosphorolysis from transglycosylation reactions. Data for 0.5 (black), 1 (purple), 2 (red) and 4 (orange) equivalents of the sugar donor $1 \mathrm{a}$ over the nucleobase are depicted. The chromatograms shown represent equilibrium states of the reactions.

A

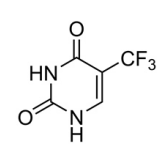

$2 f$

$\mathrm{H}_{2} \mathrm{O} / \mathrm{OH}^{-}$

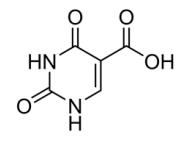

$2 f^{*}$
B
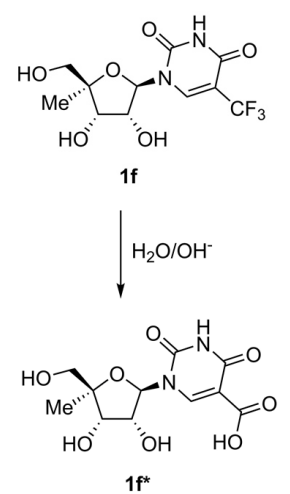

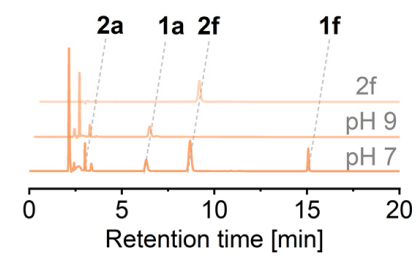

Figure S4. Transglycosylation with the trifluorinated $\mathbf{2 f}$. The nucleobase $\mathbf{2 f}$ is accepted by the enzyme and converted to the corresponding nucleoside $\mathbf{1 f}(\mathbf{A})$, but both the nucleobase and the nucleoside are labile to the alkaline conditions needed for stability of $\mathbf{3}$. Therefore, neither remaining starting material (as expected for a thermodynamically controlled reaction), nor product can be observed at $\mathrm{pH} 9$ after $4 \mathrm{~h}$ (B). At pH 7 and with 4 equivalents of $\mathbf{2 f}$, clear product formation is visible, which was confirmed by HRMS. However, significant hydrolysis is also apparent under these conditions, as is obvious by the large peak at the solvent front, corresponding to the hydrolysis product $\mathbf{2} \mathbf{f}^{*}$. Formation of $\mathbf{2} \mathbf{f}^{*}$ as well as $\mathbf{1} \mathbf{f}^{*}$ was also confirmed by HRMS analysis (Table S4, see below). 
Table S4. HRMS data for transglycosylation reactions.

$\begin{array}{ccccc}\text { Compound } & \text { Ion } & \text { Molecular formula } & \text { Predicted } \mathrm{m} / \mathrm{z} & \text { Found } \mathrm{m} / \mathrm{z} \\ \mathbf{1 b} & {[\mathrm{M}-\mathrm{H}]^{-}} & \mathrm{C}_{11} \mathrm{H}_{15} \mathrm{~N}_{2} \mathrm{O}_{6} & 271.0930 & 271.0941 \\ \mathbf{1 c} & {[\mathrm{M}-\mathrm{H}]^{-}} & \mathrm{C}_{10} \mathrm{H}_{12} \mathrm{FN}_{2} \mathrm{O}_{6} & 275.0679 & 275.0690 \\ \mathbf{1 d} & {[\mathrm{M}-\mathrm{H}]^{-}} & \mathrm{C}_{10} \mathrm{H}_{12} \mathrm{BrN}_{2} \mathrm{O}_{6} & 334.9879 & 334.9892 \\ \mathbf{1 e} & {[\mathrm{M}-\mathrm{H}]^{-}} & \mathrm{C}_{10} \mathrm{H}_{12} \mathrm{IN}_{2} \mathrm{O}_{6} & 382.9740 & 382.9750 \\ \mathbf{1 f}{ }^{[\mathrm{a}]} & {[\mathrm{M}-\mathrm{H}]^{-}} & \mathrm{C}_{11} \mathrm{H}_{12} \mathrm{~F}_{3} \mathrm{~N}_{2} \mathrm{O}_{6} & 325.0647 & 325.0658 \\ \mathbf{1 g} & {[\mathrm{M}+\mathrm{H}]^{+}} & \mathrm{C}_{11} \mathrm{H}_{16} \mathrm{~N}_{5} \mathrm{O}_{4} & 282.1202 & 282.1201 \\ \mathbf{1 h} & {[\mathrm{M}+\mathrm{H}]^{+}} & \mathrm{C}_{11} \mathrm{H}_{15} \mathrm{ClN}_{5} \mathrm{O}_{4} & 316.0813 & 316.0815 \\ \mathbf{1 i} & {[\mathrm{M}+\mathrm{H}]^{+}} & \mathrm{C}_{11} \mathrm{H}_{16} \mathrm{~N}_{6} \mathrm{O}_{4} & 297.1311 & 297.1312 \\ \mathbf{1 j} & {[\mathrm{M}-\mathrm{H}]^{-}} & \mathrm{C}_{11} \mathrm{H}_{16} \mathrm{~N}_{6} \mathrm{O}_{4} & 296.0995 & 296.1002 \\ \mathbf{1 k} & {[\mathrm{M}-\mathrm{H}]^{-}} & \mathrm{C}_{11} \mathrm{H}_{13} \mathrm{~N}_{4} \mathrm{O}_{5} & 281.0886 & 281.0898\end{array}$

[a] The corresponding hydrolysis products 5-carboxyl-uracil (2f*, $\mathrm{C}_{5} \mathrm{H}_{3} \mathrm{~N}_{2} \mathrm{O}_{4}[\mathrm{M}-\mathrm{H}]^{-}:$: 155.0093; found: 155.0104) and 4'-methyl-5-carboxyluridine (1f*, $\mathrm{C}_{11} \mathrm{H}_{13} \mathrm{~N}_{2} \mathrm{O}_{8}[\mathrm{M}-\mathrm{H}]^{-}:$: 301.0672; found: 301.0686) were also weakly detected.

Reactions with excess of nucleobase (Figure 3D) were performed with reaction mixtures of $0.25 \mathrm{mM} 1 \mathbf{a}, 0.075 \mathrm{mM}$ potassium phosphate (0.3 equivalents), $1 \mathrm{mM}$ nucleobase ( $\mathbf{2} \mathbf{b}$ or $\mathbf{2} \mathbf{i}$ ) and $50 \mu \mathrm{gL}^{-1} \mathrm{TtPyNP}(1.85 \mu \mathrm{M}, 0.7 \mathrm{~mol} \%$ with respect to the nucleobase) in $20 \mathrm{mM}$ glycine buffer $\mathrm{pH} 9$ at $60^{\circ} \mathrm{C}$ in a total volume of $50 \mu \mathrm{L}$. The reaction mixture with $\mathbf{2 i}$ additionally contained $125 \mu \mathrm{g} \mathrm{mL}^{-1}$ of the purine nucleoside phosphorylase from Geobacillus thermoglucosidasius. The reaction mixtures were incubated in a PCR cycler with lid heating $\left(70^{\circ} \mathrm{C}\right)$ for $4 \mathrm{~h}$. After the reaction, the mixtures were quenched through addition of $50 \mu \mathrm{L} \mathrm{MeOH}$, centrifuged (13,000 rpm, $10 \mathrm{~min})$ and analyzed by HPLC. Conversion was calculated based on remaining $\mathbf{1 a}$. The mixture with $\mathbf{2} \mathbf{b}$ showed a residual peak area of 1a of 104 mAUs, corresponding to $86 \%$ consumption of 1a (initial peak area of 719 mAUs under identical conditions). The mixture with $\mathbf{2} \mathbf{i}$ showed full consumption of $1 \mathbf{a}$. The HPLC chromatograms for these reactions are shown in Figure S5 and are available from the externally hosted Supplementary Information. ${ }^{[2]}$ The predicted conversions for these reactions were calculated via equation (S22) by setting $[N]_{1,0}$ to $1,[B]_{2,0}$ to 4 and $K_{N}$ to the values listed in Table S3. 
A

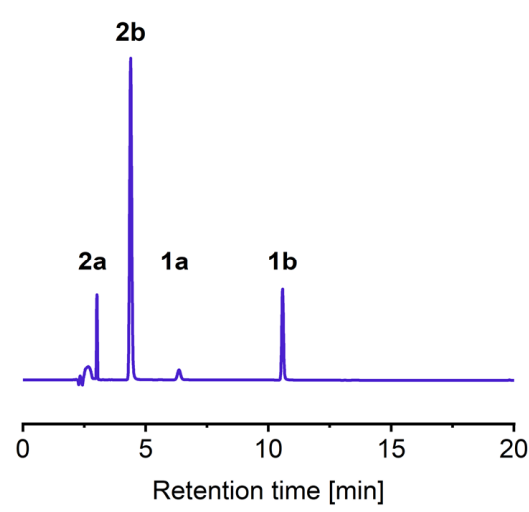

B

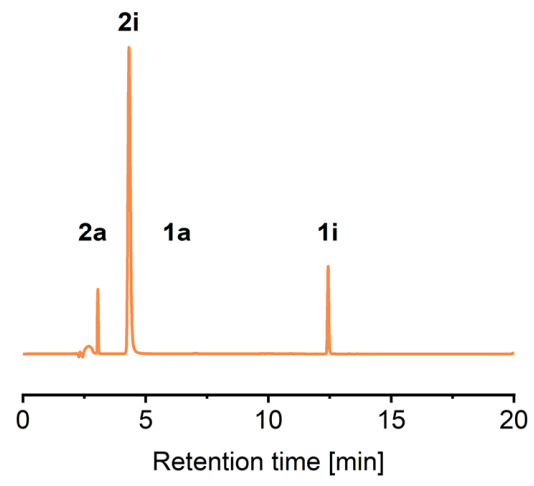

Figure S5. HPLC-DAD chromatograms $(260 \mathrm{~nm})$ for transglycosylation reactions with nucleobase excess, used for confirmation of predicted conversion.

The stability of the sugar phosphate 3 was assessed through an equilibrium shift experiment which provided stability information for this compound without having to isolate it or detect it directly (for details on the approach and equations, please see our method paper). ${ }^{[14]}$ To this end, reaction mixtures with $1 \mathrm{mM}$ 1a, $5 \mathrm{mM}$ potassium phosphate and $100 \mu \mathrm{gL}^{-1} \mathrm{TtPyNP}(3.71 \mu \mathrm{M}, 0.37 \mathrm{~mol} \%)$ in $50 \mathrm{mM}$ glycine/ $\mathrm{NaOH}$ buffer at $\mathrm{pH} 9$ in a total volume of $200 \mu \mathrm{L}$ were incubated at $60^{\circ} \mathrm{C}$ in a PCR cycler with lid heating $\left(70^{\circ} \mathrm{C}\right)$ for $2 \mathrm{~h}$. This yielded a stable equilibrium of phosphorolysis at around $56.5 \%$ conversion of $1 \mathrm{a}$ to $\mathbf{2 a}$, as determined by drawing samples of $40 \mu \mathrm{L}$ from these mixtures, quenching in $200 \mu \mathrm{L} 100 \mathrm{mM} \mathrm{NaOH}$ and analyzing as described above. This equilibrium is in accordance with the equilibrium constant of phosphorolysis $(K=0.16)$. The reaction mixtures were frozen overnight and then incubated at $98^{\circ} \mathrm{C}$ for $1.5,3$ or $5 \mathrm{~h}$ to effect hydrolysis of 3 and denaturation of the enzyme (the half-life of TtPyNP under these conditions is around $5 \mathrm{~min}$ ). These reaction mixtures with partially hydrolyzed $\mathbf{3}$ were frozen until analysis by re-equilibration. Re-equilibration was performed by addition of $20 \mu \mathrm{L}$ of a $0.7 \mathrm{~g} \mathrm{~L}^{-1}$ stock of TtPyNP in $10 \mathrm{mM}$ MOPS buffer $\left(77.7 \mu \mathrm{gL}^{-1}, 2.89 \mu \mathrm{M}, 0.28 \mathrm{~mol} \%\right.$ final concentration of active protein) and incubation at $60^{\circ} \mathrm{C}$. The reactions were allowed to reach their respective equilibria and samples of $50 \mu \mathrm{L}$ were taken after $1,1.5$ and $2 \mathrm{~h}$ after enzyme addition and quenched in $200 \mu \mathrm{L} 100 \mathrm{mM} \mathrm{NaOH}$ and analyzed via spectral unmixing as described above. The deviation of this second equilibrium from the first one was then used to calculate the hydrolytic loss of the sugar phosphate $\mathbf{3}$ according to equation (S25).

$$
[P 1 P]_{h}=\frac{K\left([P]_{0}-c_{2}[N]_{0}-c_{2}[P]_{0}+c_{2}^{2}[N]_{0}\right)-c_{2}^{2}[N]_{0}}{K c_{2}-c_{2}-K}
$$


where $[P 1 P]_{h}$ is the concentration of hydrolyzed pentose-1-phosphate ( 3 in this case) $[\mathrm{mM}], c_{2}$ is the degree of conversion in the second (post-hydrolysis) equilibrium according to equation (S26), $[P]_{0}$ and $[N]_{0}$ are the initial phosphate and nucleoside concentrations $[\mathrm{mM}]$ and $K$ is the equilibrium constant of phosphorolysis (0.16 for $1 \mathrm{a})$.

$$
c_{2}=\frac{[B]_{2}}{[N]_{0}}
$$

where $[B]_{2}$ is the concentration of the nucleobase in the second equilibrium. The half-life of $\mathbf{3}$ was then obtained by fitting residual $\mathbf{3}$ as a function of time according to equations (S27) and (S28).

$$
\begin{gathered}
{[P 1 P](t)=[P 1 P]_{1}-[P 1 P]_{h}} \\
{[P 1 P](t)=[P 1 P]_{1} e^{-\frac{t}{\tau}}}
\end{gathered}
$$

where $[P 1 P](t)$ is the pentose-1-phosphate concentration after incubation time $t[\mathrm{~h}],[P 1 P]_{1}$ is the pentose-1-phosphate concentration in the first equilibrium [mM] and $\tau$ is the mean lifetime [h] from which the half-life $t_{1 / 2}[\mathrm{~h}]$ was obtained via equation (S29).

$$
t_{1 / 2}=\tau \ln (2)
$$

The fit of these equations to the experimental data yielded $[P 1 P]_{1}=0.54 \pm 0.01 \mathrm{mM}$ and $\tau=3.08 \pm$ $0.12 \mathrm{~h}\left(\mathrm{R}^{2}=0.99\right)$ from which a half- life $t_{1 / 2}$ of $2.13 \pm 0.08 \mathrm{~h}$ was derived. The raw data and calculations for this experiment are freely available onlin $\mathrm{e}^{[2]}$ and the fit results are shown in Figure $\mathrm{S6}$. These results agree well both with the experimentally observed $[P 1 P]_{1}(0.56 \mathrm{mM})$ and the asymptotic approach to the maximum equilibrium shift predicted by equation ( $\mathrm{S} 30$ ) (77\% maximum conversion, $73.6 \%$ observed after $5 \mathrm{~h}$ hydrolytic incubation).

$$
c_{2, \max }=\frac{-Y+\sqrt{Y^{2}+4[N]_{0}(1-K)\left(c_{1}[N]_{0} K+K[P]_{0}\right)}}{2[N]_{0}(1-K)}
$$

where $c_{2, \max }$ is the maximum possible conversion in the post-hydrolysis equilibrium, $c_{1}$ is the conversion in the first (pre-hydrolysis) equilibrium, and $Y$ is a factor described by equation (S31).

$$
Y=c_{1}[N]_{0} K-c_{1}[N]_{0}+[N]_{0} K+K[P]_{0}
$$

with definitions from above. For $[N]_{0}=1 \mathrm{mM},[P]_{0}=5 \mathrm{mM}, K=0.16$ and $c_{1}=0.56(56 \%)$, equation (S30) predicts $c_{2, \max }=0.77(77 \%)$.

Considering the data reported by Bunton ${ }^{[13]}$ and us, ${ }^{[14]}$ the half-life of $2.13 \mathrm{~h}$ at $98^{\circ} \mathrm{C}$ found here suggests a half-life of $>30 \mathrm{~h}$ at $60^{\circ} \mathrm{C}$, assuming that the hydrolysis of 3 approximately follows Eyring relationships. Considering further that the concentration of free $\mathbf{3}$ in a transglycosylation reaction cannot surpass the orthophosphate concentration (which we intentionally kept low), transglycosylations under "mild" conditions such as $60^{\circ} \mathrm{C}$ run no risk of losing significant amounts of sugar phosphate to hydrolysis, unless extremely long reaction times are applied.

NMR experiments with a reaction mixture provided further insights into the stability of $\mathbf{3}$ under relevant conditions. In phosphate buffer at $\mathrm{pH}$ 7, we observed no loss of $\mathbf{3}$ from a reaction mixture 
incubated for 2 months at room temperature, indicating that the sugar phosphate is quite stable under moderate conditions. However, $\mathbf{3}$ is, like other sugar phosphates, labile to acidic conditions. At $\mathrm{pH} \approx 1$ (achieved via addition of $\mathrm{HCl}$ to a reaction mixture in equilibrium), full hydrolysis of $\mathbf{3}$ was apparent by disappearance of the signal corresponding to the anomeric proton after 1 month of incubation at room temperature (Figure S16).

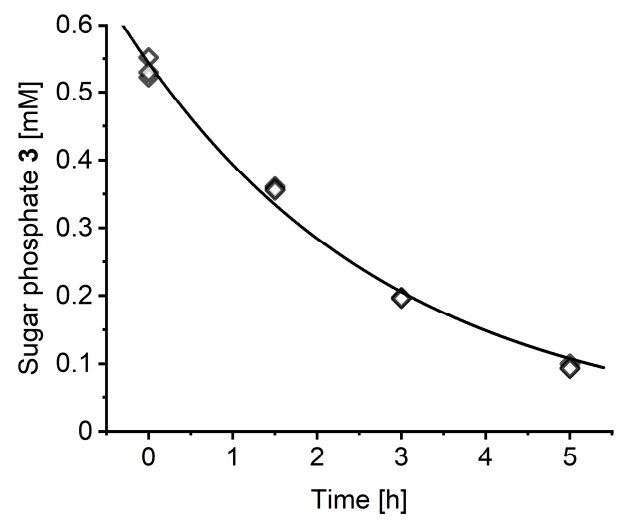

Figure S6. Hydrolysis of 3 at $98^{\circ} \mathrm{C}$ and $\mathrm{pH} 9$. 
4'-Methyl-5-iodouridine (1e) was prepared by TtPyNP-catalyzed transglycosylation. To this end, 5iodouracil (2e, $13.9 \mathrm{mg}, 0.059 \mathrm{mmol}, 5$ equivalents) and 4'-methyluridine (1a, $3 \mathrm{mg}, 0.012 \mathrm{mmol}$, 1 equivalent) were dissolved in $40 \mathrm{~mL} 10 \mathrm{mM}$ glycine buffer ( $\mathrm{pH}$ 9) with $0.09 \mathrm{mM}$ potassium phosphate (0.3 equivalents) and $4 \mu \mathrm{g} \mathrm{mL}^{-1} \mathrm{TtPyNP}(0.15 \mu \mathrm{M}, 0.05 \mathrm{~mol} \%)$. The reaction mixture was intentionally kept very diluted since TtPyNP is inhibited by nucleobases such as $\mathbf{2 e}$ and more concentrated mixtures severely compromise the productivity of the enzyme. The reaction mixture was heated to $60{ }^{\circ} \mathrm{C}$ in a water bath. After $3 \mathrm{~d}, \mathrm{HPLC}$ analysis revealed $68 \%$ conversion of $1 \mathrm{a}$ to the iodinated analogue $1 \mathrm{e}$ (please see Figure S7 and the externally hosted Supplementary Material for HPLC trace). ${ }^{[2]}$ The mixture was then concentrated to $\approx 7 \mathrm{~mL}$ in vacuo, filtered to remove precipitated protein and injected into preparative HPLC. An HPLC method consisting of 10 min isocratic elution with $1 \%$ MeCN in water, followed by linear gradient to $10 \% \mathrm{MeCN}$ over $40 \mathrm{~min}$, cleanly afforded 1e after 35 min retention time. The fraction containing $1 \mathrm{e}$ was concentrated in vacuo. Quantification of recovered $1 \mathrm{e}$ proved surprisingly difficult and inaccurate since the compound is quasi-intractable and practically insoluble in all solvents we tried. HRMS data were collected directly from the dilute eluate from the preparative HPLC and ${ }^{1} \mathrm{H}-\mathrm{NMR}$ analysis was performed with a saturated solution of $1 \mathrm{e}$ in $\mathrm{D}_{2} \mathrm{O}$ (ca. $0.5 \mathrm{mM}$, Figure S14). We estimate the isolated yield to be around $1.5-2 \mathrm{mg}$, corresponding to around $40 \%$ from $1 \mathrm{a}$. HRMS (ESI): calculated for $\mathrm{C}_{10} \mathrm{H}_{14} \mathrm{IN}_{2} \mathrm{O}_{6}[\mathrm{M}+\mathrm{H}]^{+}: 384.9897$; found: 384.9895

${ }^{1} \mathrm{H}$ NMR $\left(500 \mathrm{MHz}, \mathrm{D}_{2} \mathrm{O}\right): \delta=8.35(\mathrm{~s}, 1 \mathrm{H} ; \mathrm{H}-6), 5.98\left(\mathrm{~d},{ }^{3} \mathrm{~J}_{1^{\prime}, 2^{\prime}}=5.7 \mathrm{~Hz}, 1 \mathrm{H} ; \mathrm{H}-1^{\prime}\right), 4.48\left(\mathrm{t},{ }^{3} J_{1^{\prime}, 2^{\prime}}={ }^{3} J_{2^{\prime}, 3^{\prime}}=5.8 \mathrm{~Hz}\right.$, $\left.1 \mathrm{H} ; \mathrm{H}-2^{\prime}\right), 4.23\left(\mathrm{~d}^{3} \mathrm{~J}_{2^{\prime}, 3^{\prime}}=5.8 \mathrm{~Hz}, 1 \mathrm{H} ; \mathrm{H}-3^{\prime}\right), 3.65\left(\mathrm{~m}, 2 \mathrm{H}, \mathrm{H}-5^{\prime}\right), 1.28(\mathrm{~s}, 3 \mathrm{H} ; \mathrm{Me})$.

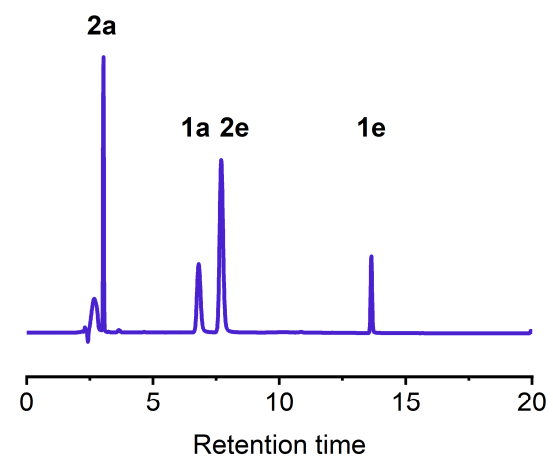

Figure S7. HPLC chromatogram for the conversion of 1 a to 1 e with 5 equivalents of $2 \mathrm{e}$. The sugar donor 1a has a peak area of $490 \mathrm{mAUs}$ and the nucleobase $2 \mathrm{a}$ a total area of $1022 \mathrm{mAUs}$, indicating that $68 \%$ of $\mathbf{1 a}$ were converted. Please note that $\mathbf{1 a} / \mathbf{2} \mathbf{a}$ and $\mathbf{1 e} / \mathbf{2 e}$ have significantly different extinction coefficients at $260 \mathrm{~nm}^{[5,6]}$ 
Docking of uridine and 1a was performed by using the crystal structure of TtPyNP (PDB ID 2dsj) as a receptor structure. Dockings were performed in AutoDock VINA ${ }^{[17]}$ implemented in YASARA (Yet Another Scientific Artificial Reality Application). All water molecules were removed from the structure prior to the docking calculation. Ligand structures were built in Chem3D and energy-minimized in YASARA. The receptor was treated as a rigid structure and the substrate was treated as a flexible molecule. Point charges on $2 \mathrm{dsj}$ were initially assigned according to the AMBER99 ${ }^{[18]}$ force field and point charges on the nucleosides were generated with AM1-BCC. ${ }^{[19]}$ Docking results obtained for each ligand with the receptor were analyzed based on docking energy $\left(\mathrm{kcal} \mathrm{mol}^{-1}\right)$. The best hit of 96 runs with $-5.94 \mathrm{kcal} \mathrm{mol}^{-1}$ free energy of binding for uridine and $-5.07 \mathrm{kcal} \mathrm{mol}^{-1}$ for 1a were used for subsequent docking of the phosphate using 32 runs. The crystal structure of GtPyNP (see below for crystallization; PDB ID 7m7k) was treated exactly as $2 \mathrm{dsj}$. Here, uridine had a binding energy of $-5.70 \mathrm{kcal} \mathrm{mol}^{-1}$ and $1 \mathrm{a}$ of $-5.60 \mathrm{kcal} \mathrm{mol}^{-1}$. The docking results are available as pdb files from the externally hosted Suppmentary Information. ${ }^{[2]}$

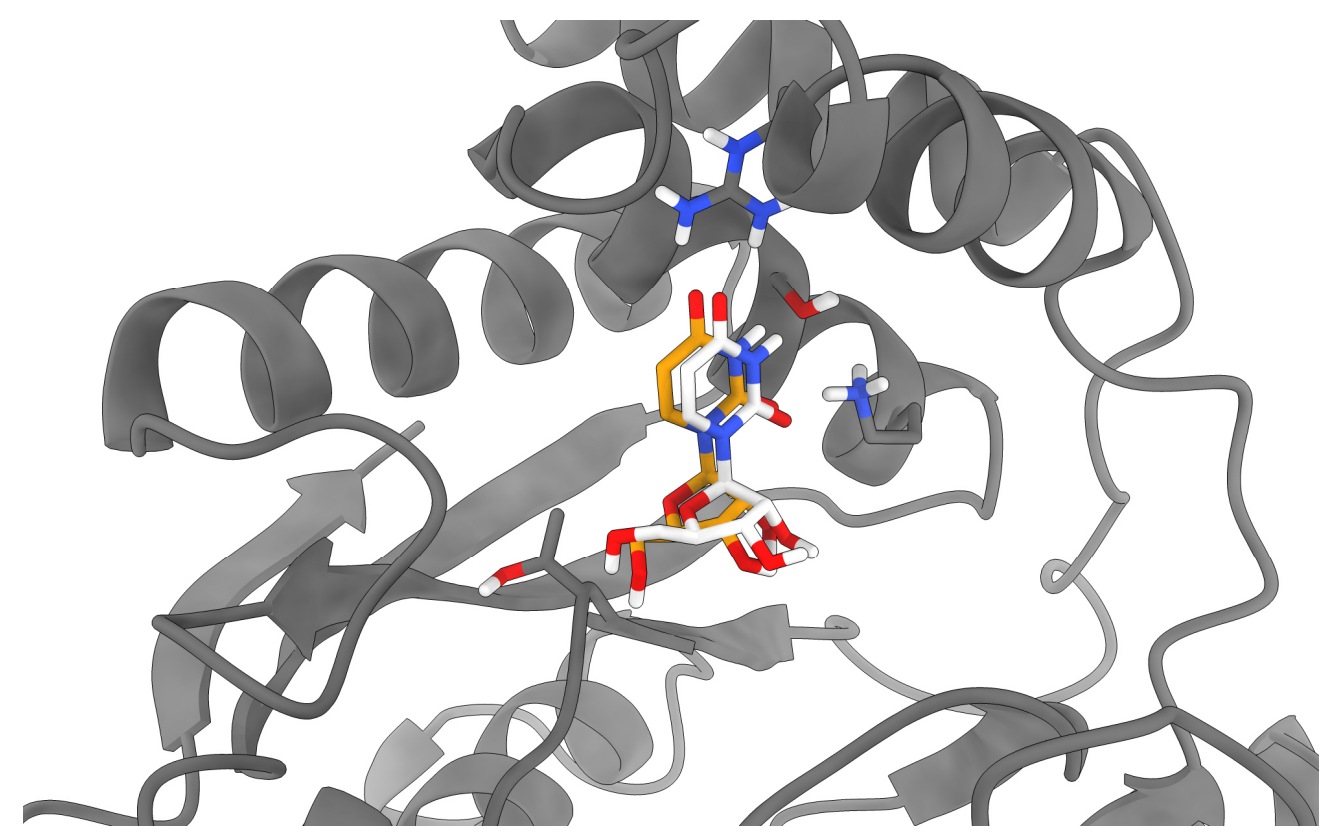

Figure S8. Superposition of the proteins with docked (orange sticks) and cocrystallized uridine (white sticks) in the GtPyNP active site. Only the original crystal structure is shown. Residues interacting with the nucleobase (R168, S183, K187) and the relevant threonine (T84) are shown as grey sticks. 


\section{Crystallographic methods}

The crystal structure of GtPyNP bound to uridine at a resolution of $1.9 \AA$ was determined to enable a comparison of TtPyNP and GtPyNP via YARASA-docking of the uridine and 1a ligands (Table S5). The structure of GtPyNP revealed the typical two-domain architecture of a NP-II family PyNP enzyme, ${ }^{[20]}$ composed of an $\alpha$-helical $(\alpha)$ domain and a mixed $\alpha$-helical and $\beta$-sheet $(\alpha / \beta)$ domain (Figure S9A). Inspection of the active site after molecular replacement revealed positive density in the unrefined $\mathrm{F}_{0^{-}}$ $F_{c}$ density map, suggesting presence of the uridine ligand within the catalytic pocket (Figure S9B). Modelling of the uridine revealed that the substrate is recruited to the active site by a set of specific interactions, mediated by polar and aliphatic side chains extending from the cleft in between the $\alpha$ and $\alpha / \beta$-domains (Figure S9C). Notably, the positive electron density in the unrefined $F_{0}-F_{c}$ density map is more pronounced for the uracil moiety, as compared to the ribose residue (Figure S9B), suggesting flexibility of the ribose, or degradation of the substrate. It is possible that sulfate, which was present in the crystallization solution, might have allowed for partial turnover of the substrate in crystallo. This phenomenon has been observed for the structurally only distantly related uridine phosphorylases, ${ }^{[21]}$ but is, to the best of our knowledge, unprecedented for pyrimidine nucleoside phosphorylases. Thus, we ascribe the lower electron density observed for the sugar moiety to the flexibility of this moiety in the open confirmation. Inspection of crystal packing contacts further revealed that GtPyNP homodimerizes via the $\alpha$-domains, as suggested from the interaction with a symmetry mate (Figure S9D) and as expected for NP-II family PyNP enzymes. ${ }^{[20]}$

The cloning, expression, and purification of GtPyNP were adjusted from the methods described above since the original construct did not crystallize. The gene encoding GtPyNP was amplified by PCR using oligonucleotides A\&B (see below) and cloned into pET-24d (Novagen) using the restriction enzymes Ncol-HF (NEB) and BamHI-HF (NEB), yielding an $\mathrm{N}$-terminally $\mathrm{His}_{6}$-tagged gene. Constructs were sequenced and subsequently transformed into E. coli BL21(DE3) cells (Novagen). Cells were inoculated in 4 L LB medium, supplemented with $12.5 \mathrm{~g} / \mathrm{L}$ lactose and $50 \mathrm{mg} / \mathrm{L}$ kanamycin. Cells were incubated overnight with vigorous shaking (150 revolutions per minute) at $30{ }^{\circ} \mathrm{C}$. Cells were harvested by centrifugation $\left(3,500 \mathrm{~g}, 20 \mathrm{~min}, 4^{\circ} \mathrm{C}\right)$ and resuspended in $20 \mathrm{~mL}$ buffer $\mathrm{A}(20 \mathrm{mM}$ HEPES-Na pH 8.0, 250 $\mathrm{mM} \mathrm{NaCl}, 20 \mathrm{mM} \mathrm{KCl}, 20 \mathrm{mM} \mathrm{MgCl}, 40 \mathrm{mM}$ imidazole) before lysis in a M-110L Microfluidizer (Microfluidics). The lysate was heated for $30 \mathrm{~min}$ at $60{ }^{\circ} \mathrm{C}$ and subsequently cleared at $47,850 \mathrm{~g}$ for $20 \mathrm{~min}$ at $4^{\circ} \mathrm{C}$. The supernatant was applied onto a $5 \mathrm{~mL}$ HisTrap FF column (GE Healthcare) for Ni-NTA affinity chromatography. After a wash step with ten column volumes (CV) of buffer A, GtPyNP was eluted with three CV of buffer B (20 mM HEPES-Na pH 8.0, $250 \mathrm{mM} \mathrm{NaCl}, 20 \mathrm{mM} \mathrm{KCl}, 20 \mathrm{mM} \mathrm{MgCl}$, $500 \mathrm{mM}$ imidazole). GtPyNP was further purified by size exclusion chromatography (SEC) using a HiLoad 26/60 Superdex 200 column (GE Healthcare) equilibrated in buffer C (20 mM HEPES-K pH 7.5, 
$150 \mathrm{mM} \mathrm{NaCl}$ ). Main peak fractions were concentrated to an absorbance at $280 \mathrm{~nm}$ of 31 arbitrary units (AU) measured on NanoDrop Lite Spectrophotometer (Thermo Fisher Scientific), corresponding to an approximate concentration of $68 \mathrm{~g} \mathrm{~L}^{-1}$.

Oligonucleotides

\section{A: 5'-TATACCATGGGCCATCACCATCACCATCACGTCGATTTAATTGCG-3' \\ B: 5'-TAATGGATCCTTATGAAATGGTTTCG-3'}

For crystallization, uridine was dissolved in buffer $C$ to a concentration of $25.8 \mathrm{mM}$. Purified GtPyNP $\left(20 \mathrm{~g} \mathrm{~L}^{-1}\right)$ and uridine $(10 \mathrm{mM})$ were combined in buffer $\mathrm{C}$ and subjected to crystallization screening by sitting-drop vapor diffusion at $20^{\circ} \mathrm{C}$ using JCSG core suites I-IV (QIAGEN). Crystals appeared in a broad range of conditions within minutes up to a day. Well diffracting crystals grew within days in drops containing $0.75 \mu \mathrm{L}$ GtPyNP-Uridine and $0.75 \mu \mathrm{L}$ crystallization solution (0.2 M Ammonium sulfate and $20 \%$ PEG3350). Cryo-protectant was prepared by adding $20 \%(\mathrm{v} / \mathrm{v})$ glycerol to the crystallization buffer. Crystals were transferred into the cryo-protectant solution, subsequently flash-frozen, and stored in liquid nitrogen.

Diffraction data were collected at Beamline ID29 of the European Synchrotron Radiation Facility (Greanoble, France). ${ }^{[22]}$ Data were processed with the XDS program package for data reduction, ${ }^{[23]}$ and merging and scaling was performed using the AIMLESS program as implemented in the CCP4 package. ${ }^{[24]}$ The data set was solved by molecular replacement using the crystal structure of Bacillus stearothermophilus PyNP (PDB ID 1brw, chain A) ${ }^{[25]}$ via the CCP4 implemented program Phaser. ${ }^{[26]}$ $\operatorname{Coot}^{[27]}$ in combination with phenix.refine, as implemented in the Phenix software suite, ${ }^{[28]}$ were used for iterative model building and refinement. 
A
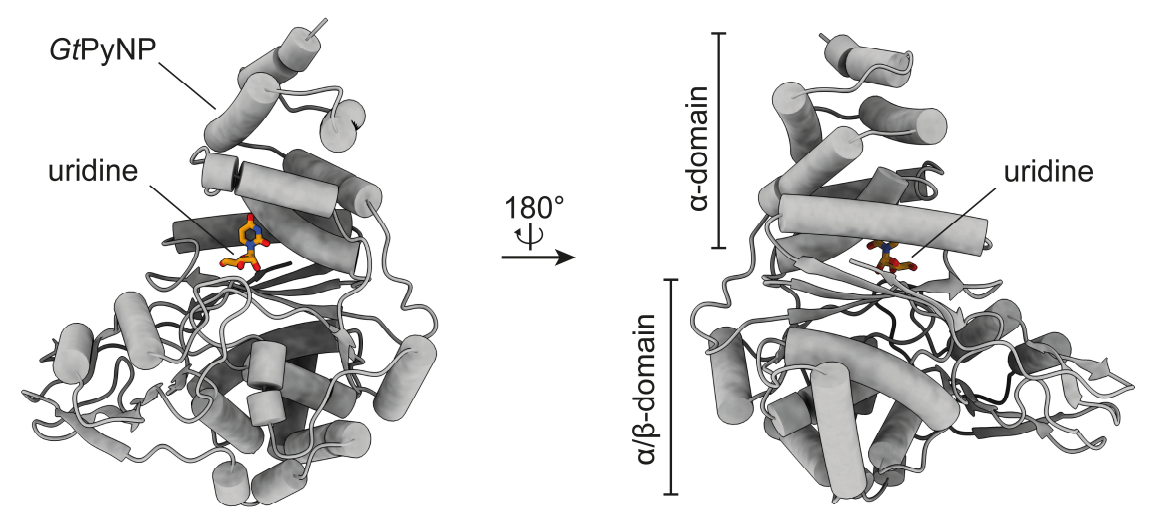

B

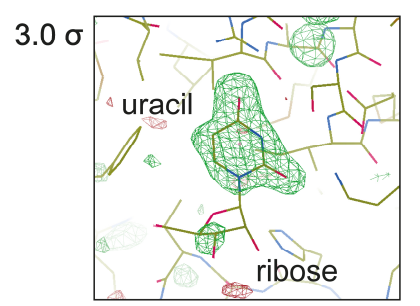

C
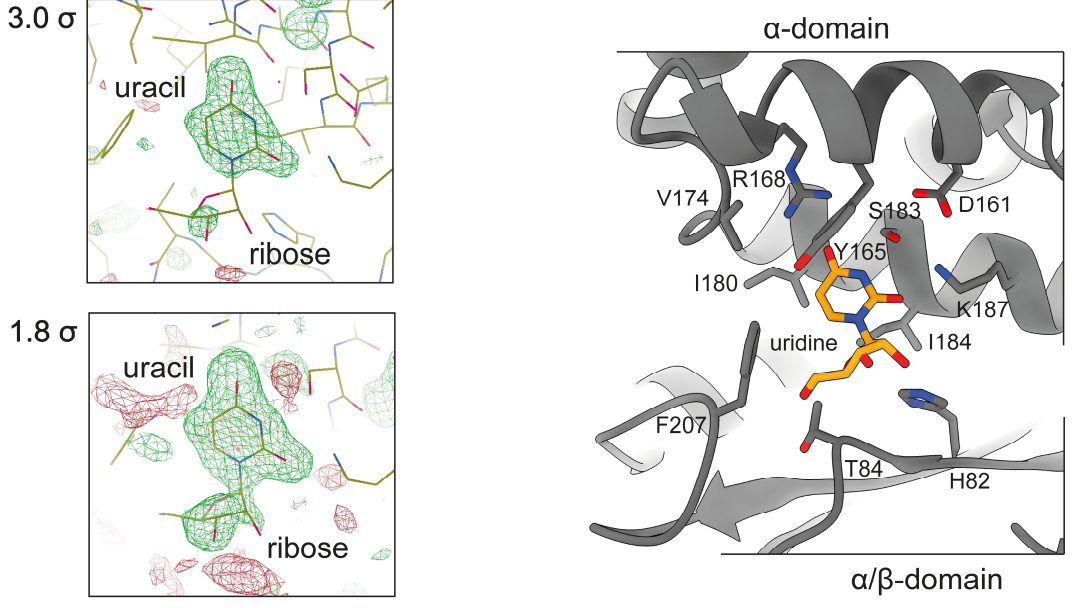

D

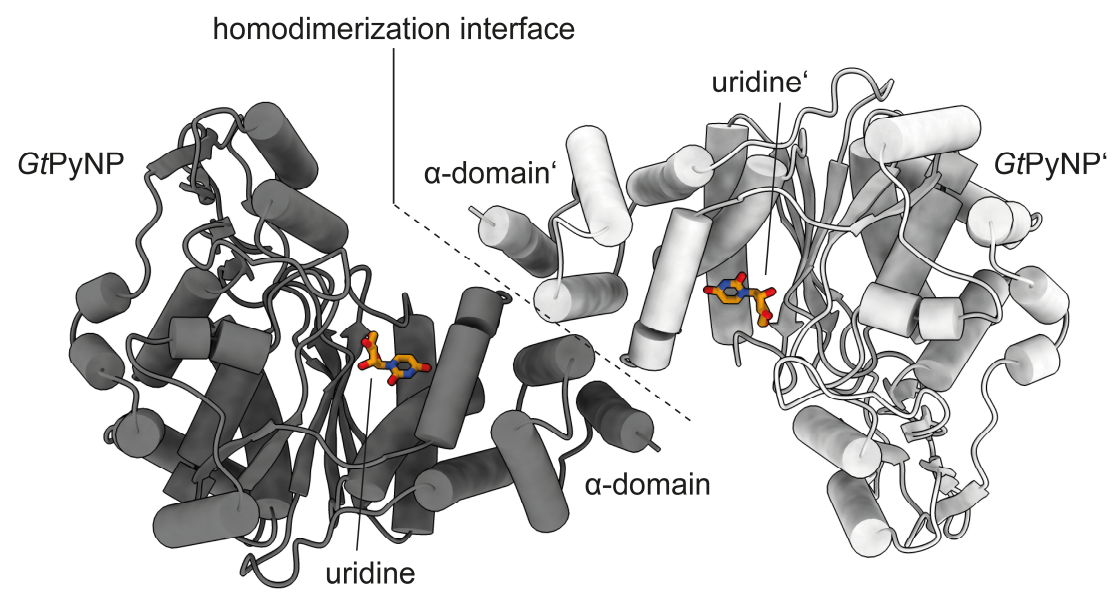

Figure S9: Crystal structure of uridine-bound GtPyNP. (A) Structure of uridine (orange sticks) bound to GtPyNP (grey cartoon) in two $180^{\circ}$-rotated orientations. (B) Unrefined $\mathrm{F}_{\mathrm{o}}-\mathrm{F}_{\mathrm{c}}$ density map at $3.0 \mathrm{\sigma}$ (above) and $1.8 \sigma$ (below), as observed after molecular replacement. Green mesh indicates positive density and red mesh indicates negative density. The refined GtPyNP-uridine model is shown as sticks. (C) Close-up on the active site formed in the cleft in between the $\alpha$-and $\alpha / \beta$-domains (coloring as in 
(A)). (D) S-shaped homodimer formed by GtPyNP (dim grey) and symmetry mate GtPyNP' (silver; symmetry operator: $-Y,-X,-Z-1 / 2)$. The dotted line highlights the dimerization interface of the $\alpha$-domains.

Table S5: Crystallographic Table*

GtPyNP-uridine (PDB-ID: 7m7k)

\begin{tabular}{|c|c|c|}
\hline & $\begin{array}{l}\text { Method } \\
\text { MR-Model }\end{array}$ & $\begin{array}{l}\text { Molecular Replacement } \\
\text { PDB ID: } 1 \text { brw, chain }{ }^{\left[{ }^{[25]}\right.}\end{array}$ \\
\hline \multirow[t]{13}{*}{ Data collection } & Wavelength $(\AA ̊)$ & 0.979 \\
\hline & Space group & P 41212 \\
\hline & Cell dimensions & \\
\hline & $a, b, c(\AA)$ & $84.26,84.26,121.69$ \\
\hline & $\alpha, \beta, \gamma(\AA)$ & $90,90,90$ \\
\hline & Resolution (Å) & $49.33-1.89 \quad(1.96-1.89)$ \\
\hline & Unique reflections & $35436(3340)$ \\
\hline & $R_{\text {merge }}$ & $0.193 \quad(1.249)$ \\
\hline & $R_{\text {pim }}$ & $0.052 \quad(0.362)$ \\
\hline & $I / \sigma l$ & $13.26 \quad(2.01)$ \\
\hline & $\mathrm{CC} 1 / 2$ & $0.999 \quad(0.489)$ \\
\hline & Completeness (\%) & 99.51 (95.29) \\
\hline & Redundancy & $13.9 \quad(12.6)$ \\
\hline \multirow[t]{23}{*}{ Refinement } & Resolution ( $\AA$ ) & $49.33-1.89 \quad(1.96-1.89)$ \\
\hline & No. reflections & \\
\hline & Total & 35430 (3339) \\
\hline & Rfree & $1759(174)$ \\
\hline & Rwork / Rfree & $17.4 / 20.8$ \\
\hline & No. atoms non-hydrog & sen atoms \\
\hline & Macromolecules & 3246 \\
\hline & Ligands & 15 \\
\hline & Water & 360 \\
\hline & Protein residues & 432 \\
\hline & Ramachandran & \\
\hline & Favoured (\%) & 98.14 \\
\hline & Allowed (\%) & 1.86 \\
\hline & Outliers (\%) & 0 \\
\hline & Rotamer outliers (\%) & 0.58 \\
\hline & Clashscore & 4.7 \\
\hline & $B$-factors & \\
\hline & Macromolecules & 31.54 \\
\hline & Ligands & 66.55 \\
\hline & Water & 36.61 \\
\hline & R.m.s. Deviations & \\
\hline & Bond lengths $(\AA ̊)$ & 0.007 \\
\hline & Bond angles $\left({ }^{\circ}\right)$ & 0.83 \\
\hline
\end{tabular}

*Data was derived from a single crystal. Values in parentheses are for the highest resolution shell. 
NMR spectra (the full raw data are freely available online ${ }^{[2]}$ and tabulated data are listed above)

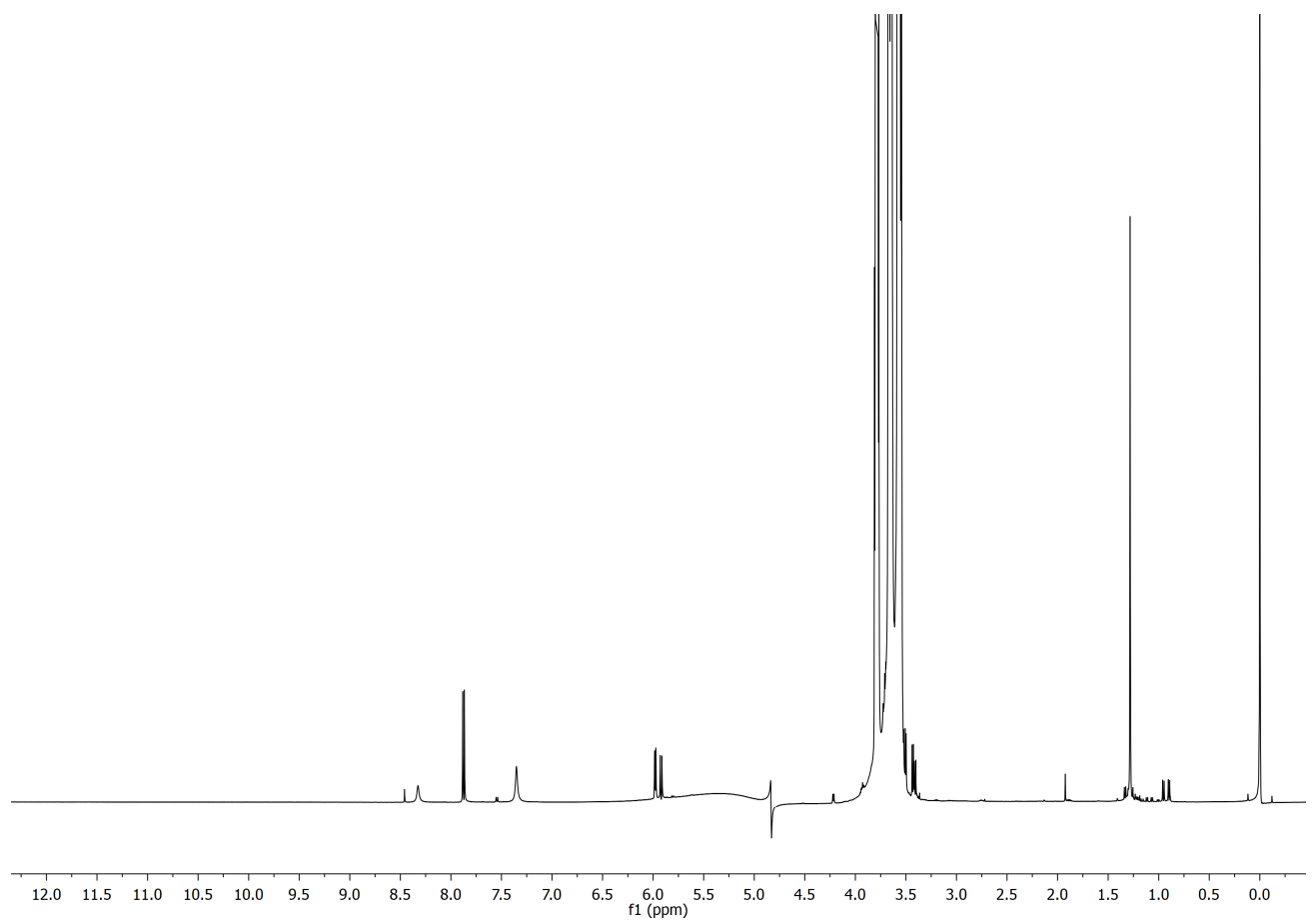

Figure S10. ${ }^{1} \mathrm{H}$ NMR $\left(700 \mathrm{MHz}, \mathrm{H}_{2} \mathrm{O} / \mathrm{D}_{2} \mathrm{O}\right.$, with water suppression, $5 \%(\mathrm{v} / \mathrm{v})$ glycerol) of the phosphorolysis reaction mixture of $1 \mathrm{a}$ and TtPyNP prior to the reaction (described on page 9).

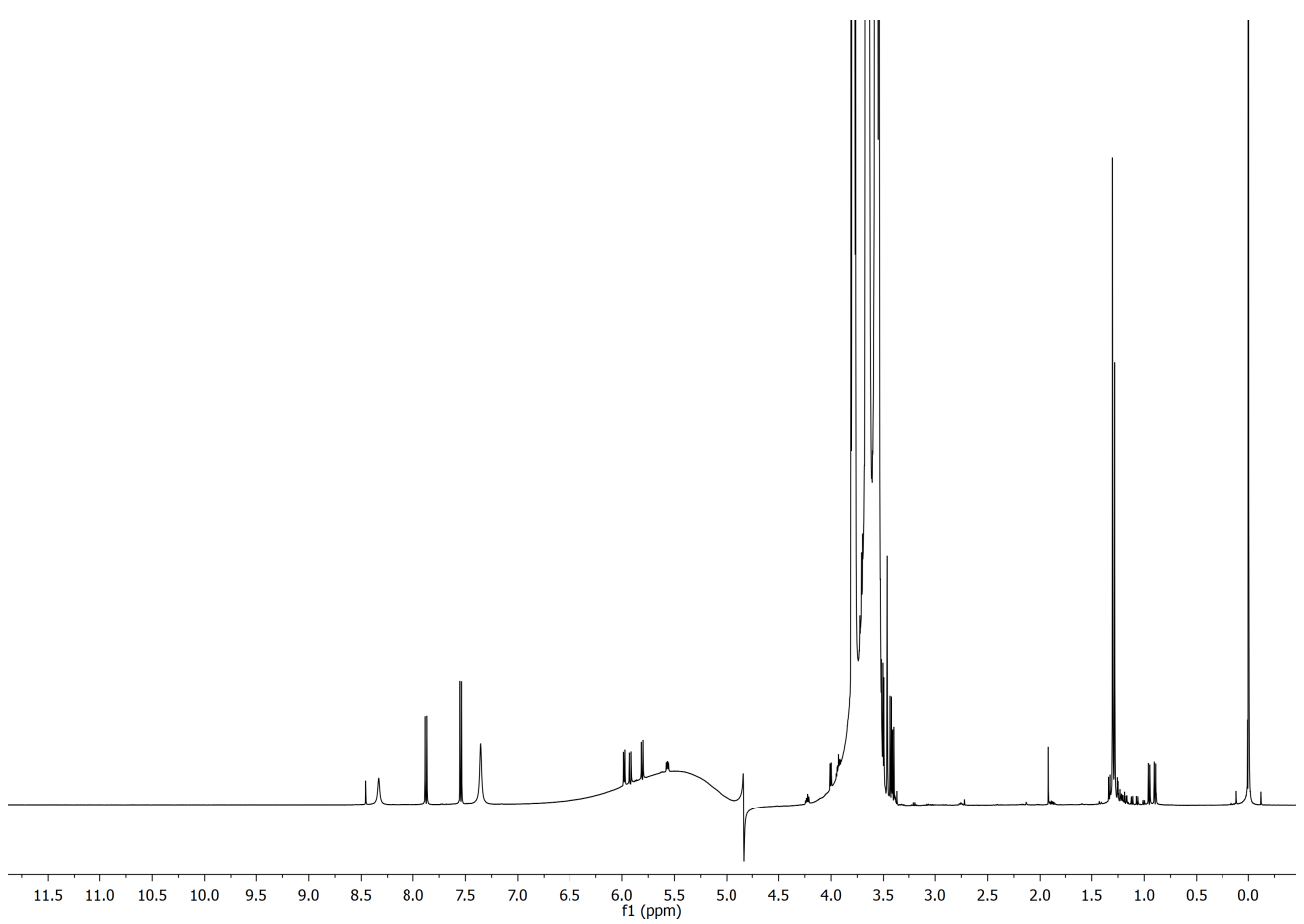

Figure S11. ${ }^{1} \mathrm{H}$ NMR (700 MHz, $\mathrm{H}_{2} \mathrm{O} / \mathrm{D}_{2} \mathrm{O}$, with water suppression, $5 \%(\mathrm{v} / \mathrm{v})$ glycerol) of the phosphorolysis reaction mixture of 1a and TtPyNP after the reaction (described on page 9). 


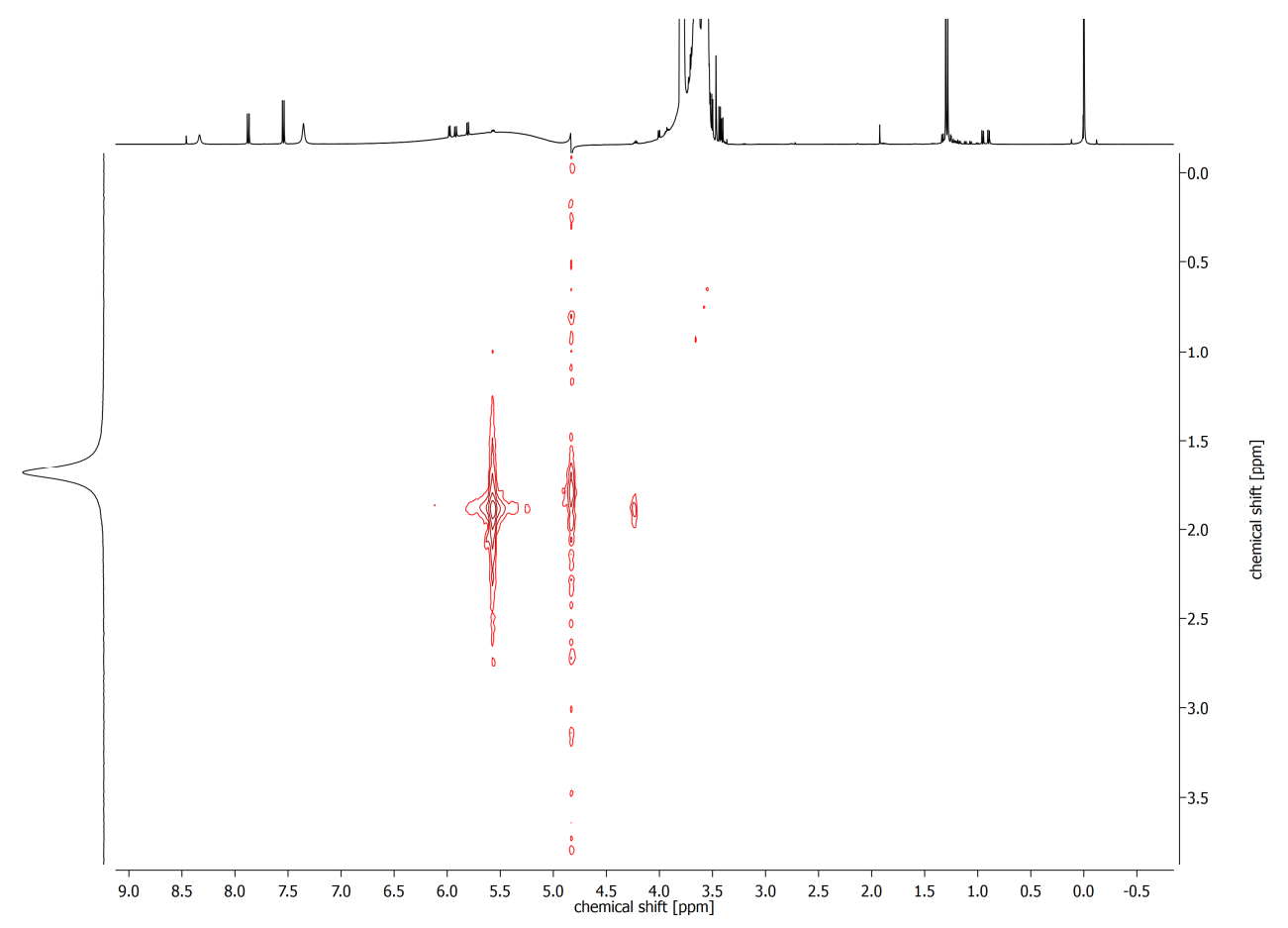

Figure S12. ${ }^{1} \mathrm{H}^{31} \mathrm{P}-\mathrm{HMQC}\left(700 \mathrm{MHz}, \mathrm{H}_{2} \mathrm{O} / \mathrm{D}_{2} \mathrm{O}\right.$, with water suppression, $5 \%$ (v/v) glycerol) spectrum of the phosphorolysis reaction mixture of 1a and TtPyNP after the reaction (described on page 9).

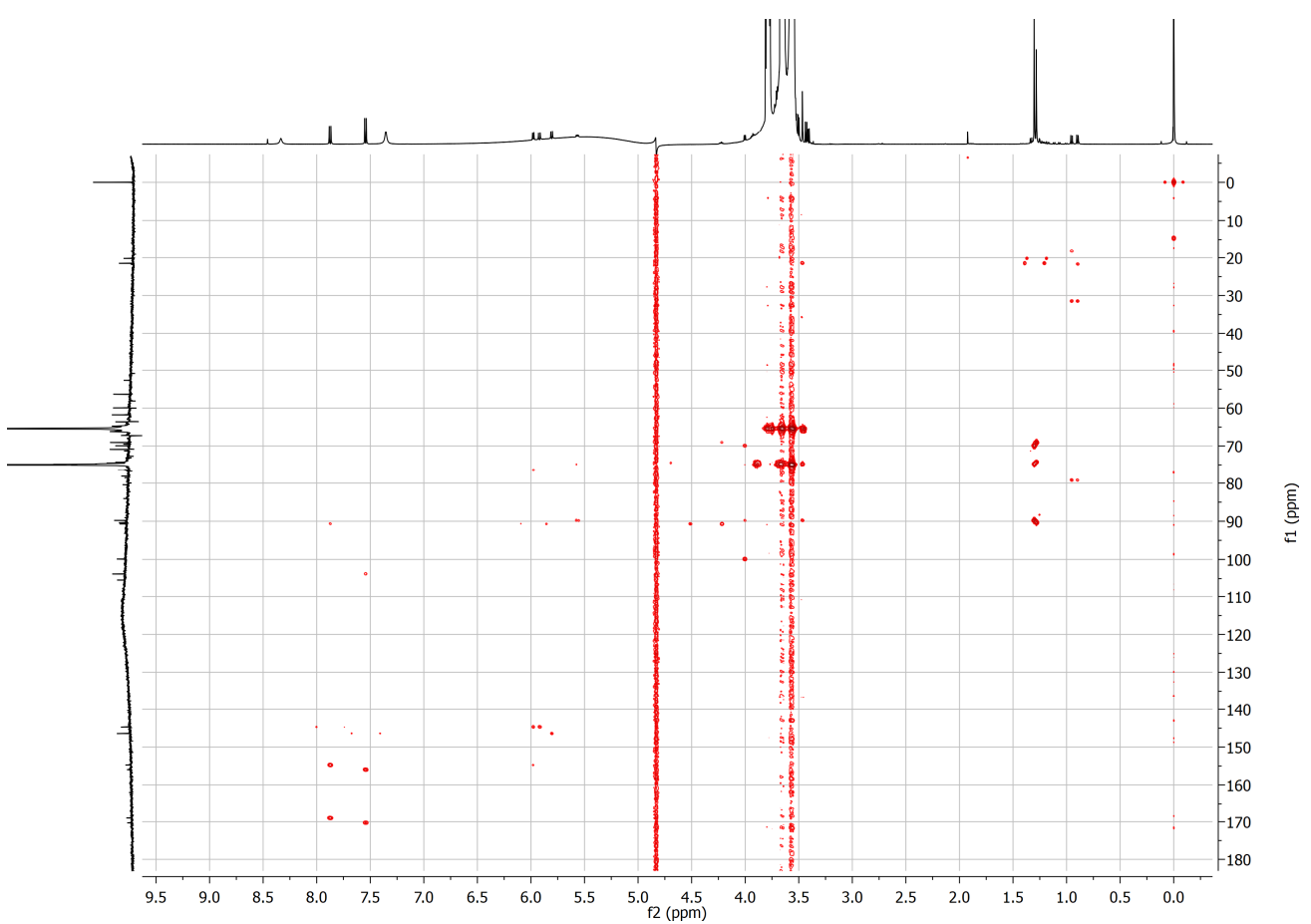

Figure S13. ${ }^{1} \mathrm{H},{ }^{13} \mathrm{C}-\mathrm{HMBC}\left(700 \mathrm{MHz}, \mathrm{H}_{2} \mathrm{O} / \mathrm{D}_{2} \mathrm{O}\right.$, with water suppression, $5 \%$ (v/v) glycerol) spectrum of the phosphorolysis reaction mixture of 1a and TtPyNP after the reaction (described on page 9). 


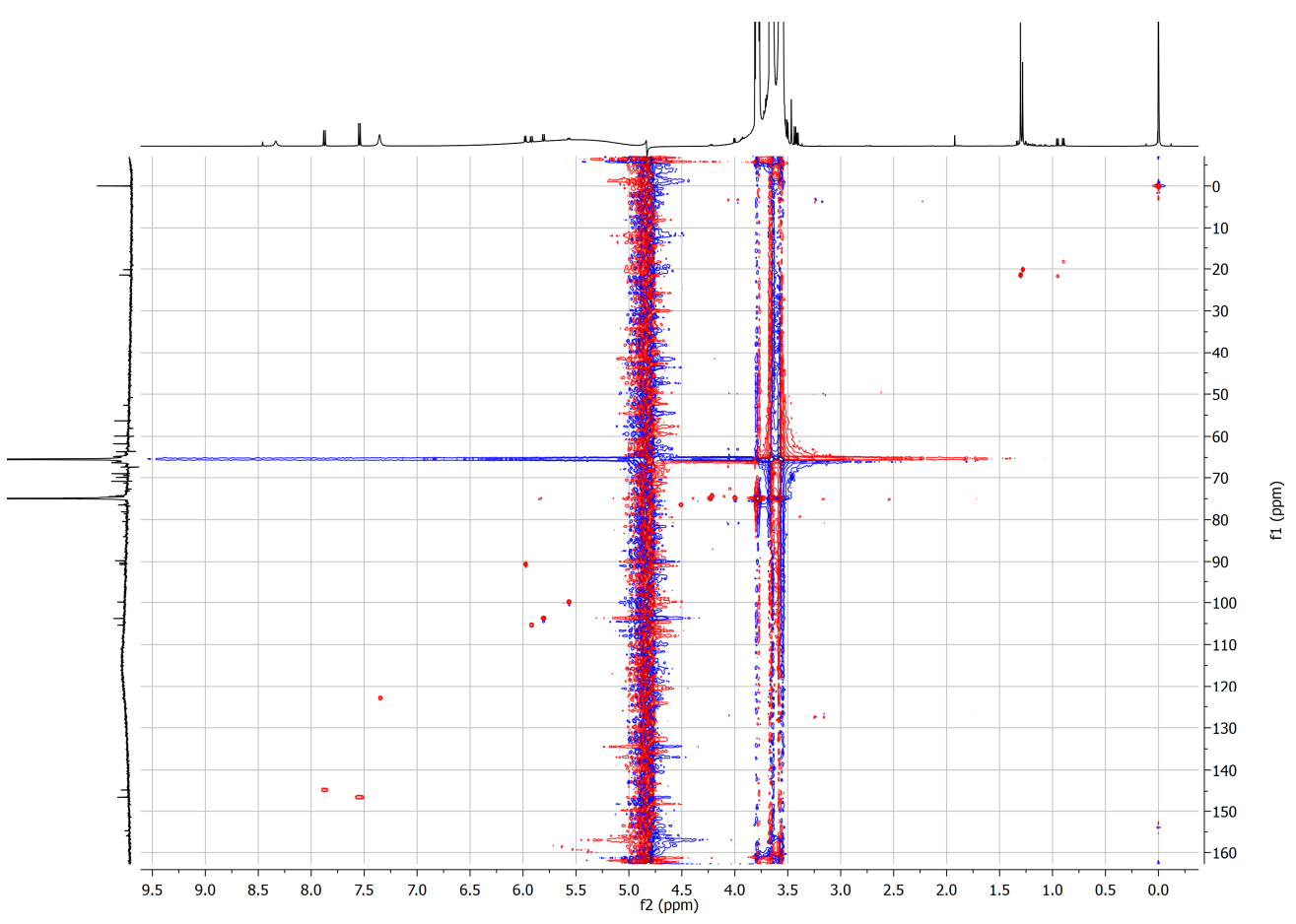

Figure S14. ${ }^{1} \mathrm{H},{ }^{13} \mathrm{C}-\mathrm{HSQC}\left(700 \mathrm{MHz}, \mathrm{H}_{2} \mathrm{O} / \mathrm{D}_{2} \mathrm{O}\right.$, with water suppression, $5 \%(\mathrm{v} / \mathrm{v})$ glycerol) spectrum of the phosphorolysis reaction mixture of 1a and TtPyNP after the reaction (described on page 9).

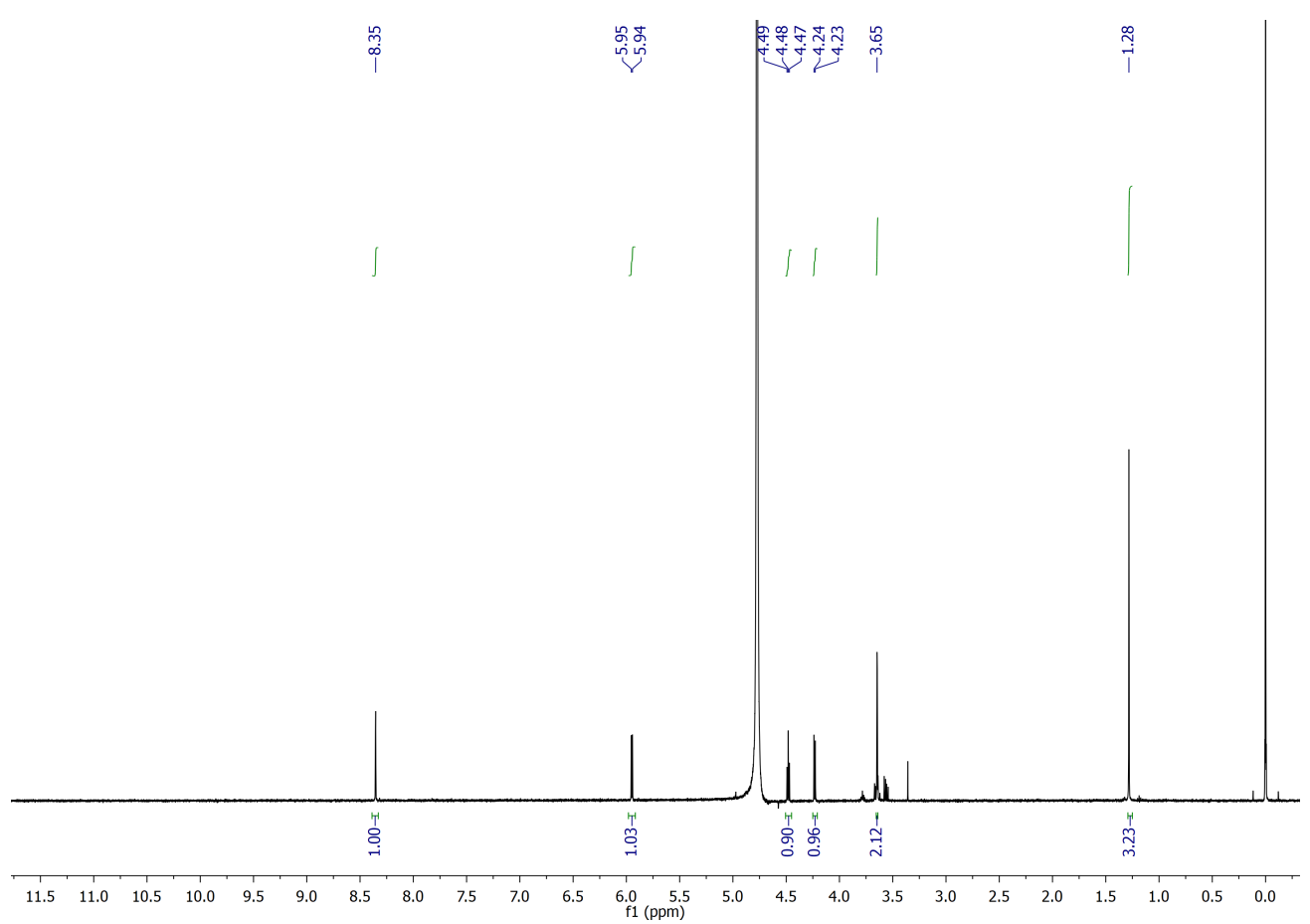

Figure S15. ${ }^{1} \mathrm{H}$ NMR $\left(500 \mathrm{MHz}, \mathrm{D}_{2} \mathrm{O}\right)$ of a saturated solution of isolated $1 \mathrm{e}$ in $\mathrm{D}_{2} \mathrm{O}$ (ca. $0.5 \mathrm{mM}$ ). 


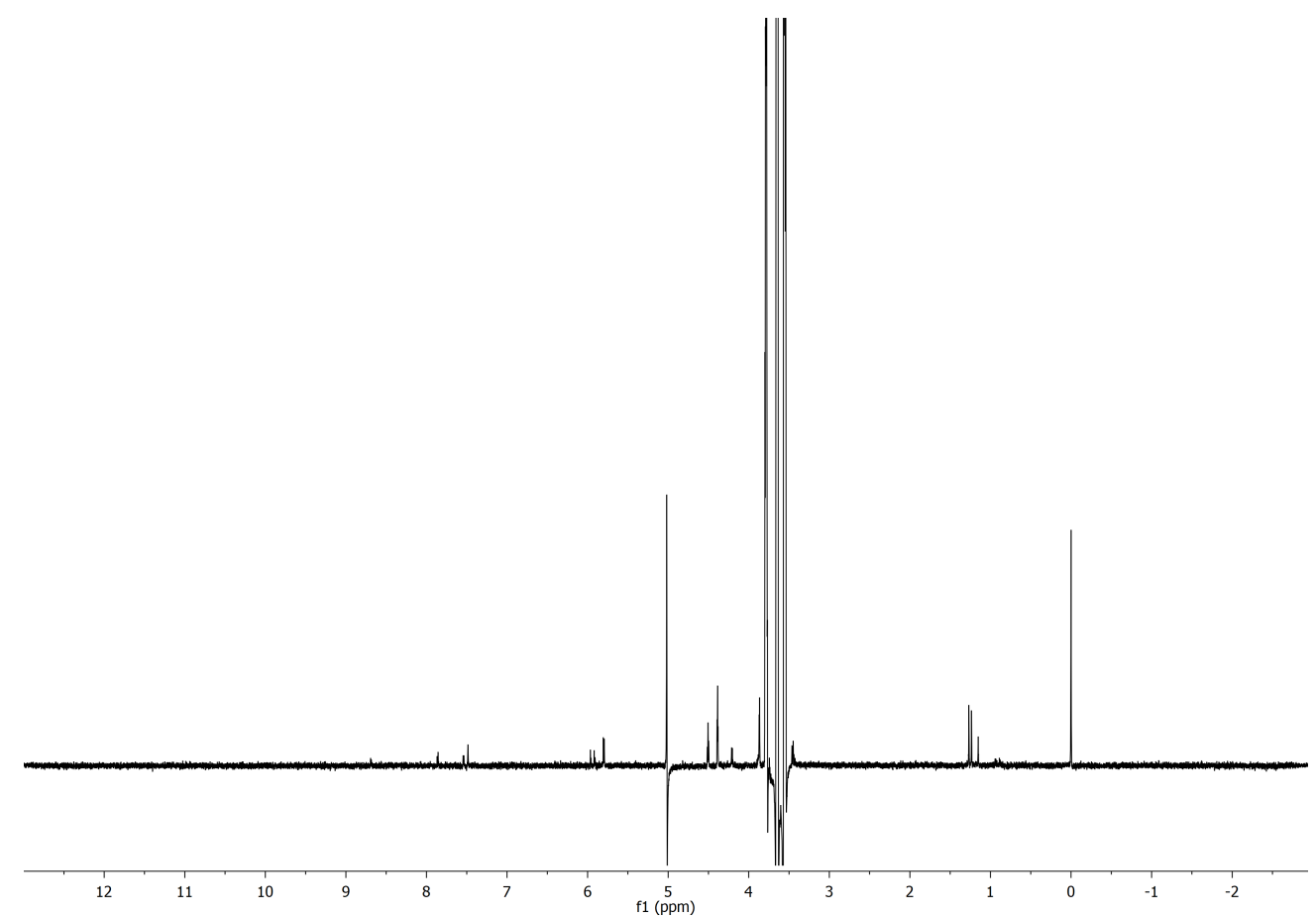

Figure S16. ${ }^{1} \mathrm{H}$ NMR (500 MHz, $\mathrm{H}_{2} \mathrm{O} / \mathrm{D}_{2} \mathrm{O}$, with water suppression, $5 \%(\mathrm{v} / \mathrm{v})$ glycerol) of the phosphorolysis reaction mixture of 1a and TtPyNP (described on page 9) after addition of $\mathrm{HCl}$ and 1 month of incubation at $\mathrm{pH} 1$. 


\section{Supplementary References}

[1] Brand, A.; Allen, L.; Altman, M.; Hlava, M.; Scott, J. (2015) Beyond authorship: attribution, contribution, collaboration, and credit. Learn. Publ. 28, 151-155.

[2] Kaspar, F. (2021) DOI 10.5281/zenodo.4630205.

[3] Köllmann, C.; Sake, S. M.; Jones, P. G.; Pietschmann, T.; Werz, D. B. (2020) Protecting-GroupMediated Diastereoselective Synthesis of C4'-Methylated Uridine Analogs and Their Activity against the Human Respiratory Syncytial Virus. J. Org. Chem. 85, 4267-4278.

[4] Harris, R. K.; Becker, E. D.; Cabral de Menezes, S. M.; Goodfellow, R.; Granger, P. (2002) NMR nomenclature: nuclear spin properties and conventions for chemical shifts. IUPAC Recommendations 2001. International Union of Pure and Applied Chemistry. Physical Chemistry Division. Commission on Molecular Structure and Spectroscopy. Magn. Reson. Chem. 40, 489-505.

[5] Kaspar, F.; Giessmann, R. T.; Krausch, N.; Neubauer, P.; Wagner, A.; Gimpel, M. (2019) A UV/Vis Spectroscopy-Based Assay for Monitoring of Transformations Between Nucleosides and Nucleobases. Methods Protoc. 2, 60.

[6] Kaspar, F.; Giessmann, R. T.; Westarp, S.; Hellendahl, K. F.; Krausch, N.; Thiele, I.; Walczak, M. C.; Neubauer, P.; Wagner, A. (2020) Spectral Unmixing-Based Reaction Monitoring of Transformations between Nucleosides and Nucleobases. ChemBioChem 21, 2604.

[7] Pettersen, E. F.; Goddard, T. D.; Huang, C. C.; Meng, E. C.; Couch, G. S.; Croll, T. I.; Morris, J. H.; Ferrin, T. E. (2021) UCSF ChimeraX: Structure visualization for researchers, educators, and developers. Protein Sci. 30, 70-82.

[8] Szeker, K.; Zhou, X.; Schwab, T.; Casanueva, A.; Cowan, D.; Mikhailopulo, I. A.; Neubauer, P. (2012) Comparative investigations on thermostable pyrimidine nucleoside phosphorylases from Geobacillus thermoglucosidasius and Thermus thermophilus. J. Mol. Catal. B Enzym. 84, 27-34.

[9] Kaspar, F.; Neubauer, P.; Kurreck, A. (2020) The Peculiar Case of the Hyperthermostable Pyrimidine Nucleoside Phosphorylase from Thermus thermophilus. ChemBioChem 22, 1385.

[10] Kaspar, F.; Giessmann, R. T.; Neubauer, P.; Wagner, A.; Gimpel, M. (2020) Thermodynamic Reaction Control of Nucleoside Phosphorolysis. Adv. Synth. Catal. 362, 867-876.

[11] Cornish-Bowden, A. (1979) Fundamentals of Enzyme Kinetics.

[12] Gasteiger, E.; Hoogland, C.; Gattiker, A.; Duvaud, S.; Wilkons, M. R.; Appel, R. D.; Bairoch, A. (2005) Protein Identification and Analysis Tools on the ExPASy Server. in Proteomics Protoc. Handb. (Ed.: J. Walker), Humana Press, pp. 571-607.

[13] Bunton, C. A.; Humeres, E. (1969) The hydrolyses of alpha-D-ribose and -glucose 1phosphates. J. Org. Chem. 34, 572-576.

[14] Kaspar, F.; Neubauer, P.; Kurreck, A. (2021) Kinetic Analysis of the Hydrolysis of Pentose-1phosphates through Apparent Nucleoside Phosphorolysis Equilibrium Shifts. ChemPhysChem 22, 283-287.

[15] Eyring H. (1935) The Activated Complex in Chemical Reactions. J. Chem. Phys. 3, 107-115.

[16] Kaspar, F.; Giessmann, R. T.; Hellendahl, K. F.; Neubauer, P.; Wagner, A.; Gimpel, M. (2020) General Principles for Yield Optimization of Nucleoside Phosphorylase-Catalyzed Transglycosylations. ChemBioChem 21, 1428-1432. 
[17] Trott, O.; Olson, A. J. (2010) AutoDock Vina: Improving the speed and accuracy of docking with a new scoring function, efficient optimization, and multithreading. J. Comput. Chem. 31, 455-461.

[18] Wang, J.; Cieplak, P.; Kollman, P. A. (2000) How well does a restrained electrostatic potential (RESP) model perform in calculating conformational energies of organic and biological molecules? J. Comput. Chem. 21, 1049-1074.

[19] Jakalian, A.; Jack, D. B.; Bayly, C. I. (2002) Fast, efficient generation of high-quality atomic charges. AM1-BCC model: II. Parameterization and validation. J. Comput. Chem. 23, 16231641.

[20] Pugmire, M. J.; Ealick, S. E. (2002) Structural analyses reveal two distinct families of nucleoside phosphorylases. Biochem. J. 361, 1-25.

[21] Paul, D.; O'Leary, S. E.; Rajashankar, K.; Bu, W.; Toms, A.; Settembre, E. C.; Sanders, J. M.; Begley, T. P.; Ealick, S. E. (2010) Glycal Formation in Crystals of Uridine Phosphorylase. Biochemistry 49, 3499-3509.

[22] Gabadinho, J.; Beteva, A.; Guijarro, M.; Rey-Bakaikoa, V.; Spruce, D.; Bowler, M. W.; Brockhauser, S.; Flot, D.; Gordon, E. J.; Hall, D. R. et al. (2010) MxCuBE: a synchrotron beamline control environment customized for macromolecular crystallography experiments. J. Synchrotron Radiat. 17, 700-707.

[23] Kabsch, W. (2010) XDS. Acta Crystallogr. Sect. D 66, 125-132.

[24] Winn, M. D.; Ballard, C. C.; Cowtan, K. D.; Dodson, E. J.; Emsley, P.; Evans, P. R.; Keegan, R. M.; Krissinel, E. B.; Leslie, A. G. W.; McCoy, A. et al. (2011) Overview of the CCP4 suite and current developments. Acta Crystallogr. Sect. D 67, 235-242.

[25] Pugmire, M. J.; Ealick, S. E. (1998) The crystal structure of pyrimidine nucleoside phosphorylase in a closed conformation. Structure 6, 1467-1479.

[26] McCoy, A. J.; Grosse-Kunstleve, R. W.; Adams, P. D.; Winn, M. D.; Storoni, L. C.; Read, R. J. (2007) Phaser crystallographic software. J. Appl. Crystallogr. 40, 658-674.

[27] Emsley, P.; Cowtan, K. (2004) Coot: model-building tools for molecular graphics. Acta Crystallogr. Sect. D 60, 2126-2132.

[28] Adams, P. D.; Afonine, P. V.; Bunkoczi, G.; Chen, V. B.; Davis, I. W.; Echols, N.; Headd, J. J.; Hung, L.-W.; Kapral, G. J.; Grosse-Kunstleve, R. W.; et al. (2010) PHENIX: a comprehensive Python-based system for macromolecular structure solution. Acta Crystallogr. Sect. D 66, 213-221. 